\title{
Chapter 5 \\ Case Study 2: Oilseed Rape (Brassica napus L.)
}

\author{
Johannes L. Frieß, Broder Breckling, Kathrin Pascher \\ and Winfried Schröder
}

\section{Intention and Scope of the Case Study Oilseed Rape (Brassica napus)}

SPAGE (Self-Propagating Artificial Genetic Element) technologies allow for a proliferation of genetic information on the population level at a higher rate than usual Mendelian inheritance. Currently projected developments of SPAGE mainly aim at a reduction or suppression of animal populations which are considered to be harmful or undesirable (Oye et al. 2014). However, the application of SPAGE is not limited to animals only. In principle, also plant populations can be targeted (National Academies of Sciences 2016). The GeneTip case study on oilseed rape (Brassica napus) is intended to assess, which interactions play a role in a plant-specific context to address relevant ecological interactions that need to be fully explored in order to estimate potential risks. For such an assessment, oilseed rape is of particular interest though no application developments are known to be currently on the way. Apart from that, first experiments for instance increased shatter resistance to avoid seed loss during harvest are already in development (Braatz et al. 2017).

Brassica napus exhibits relatively well studied environmental interaction types that are prototypic for many other plants, in particular addressing relations of cultivation and genetic exchange with feral and weedy species (Landbo et al. 1996;

B. Breckling · W. Schröder

Chair of Landscape Ecology, University of Vechta, Vechta, Germany

\section{J. L. Frieß $(\bowtie)$}

Institute of Safety/Security and Risk Sciences, University of Natural Resources and Life Sciences (BOKU), Vienna, Austria

e-mail: johannesfriess@gmx.net

K. Pascher

Department of Integrative Biology and Biodiversity Research, Zoology, University of Natural Resources and Life Sciences, Vienna, Austria 
Pascher et al. 2006, 2010, 2017). It is one of the species that has its centre of origin in Europe, and thus a specific responsibility of the European Union to secure sustainability conditions for related wild species may be implied. An analysis of the environmental network of oilseed rape helps to understand the context that is of comparable importance with the prerequisites for various other plant species.

Oilseed rape exemplifies the following risk relevant relations:

The plant is a main crop in Central European areas with significant economic value. It is traded world-wide to a relevant economic extent. Oilseed rape has a variety of technical uses including biodiesel or lubricant for industrial machinery (Moser et al. 2013). It is most widely applied for food (e.g. edible oil, honey) as well as in animal feed (Sarwar et al. 2013). The pollen of the plant is dispersed over very large distances by wind and insects, in rare cases even up to $26 \mathrm{~km}$ (Devaux et al. 2005; Ramsay et al. 2003). Not only does oilseed rape frequently grow as a volunteer and establish feral populations, it also forms seed banks, which are viable for up to 15-20 years (D’Hertefeldt et al. 2008; Lutman 1993; Schlink 1998a, b). Its far reaching spatio-temporal spread and persistence is further coupled with a remarkable extent of hybridisation potential to a large number of related species within the Brassica genus and partly even to other genera such as Raphanus, Sinapis and Erucastrum (Chèvre et al. 2004). Gene flow is rather well studied and models on the population dynamics exist (Colbach et al. 2001a, b; Habekotté 1997a; Middelhoff et al. 2011). Furthermore, extensive studies on the occurrence of transgene escapees from genetically modified (GM) oilseed rape cultivation and in countries without cultivation of GM oilseed rape have been conducted (Knispel and McLachlan 2010; Simard et al. 2005; Warwick et al. 2003, 2008; Yoshimura et al. 2006). It was also shown, that a self-organised formation of gene stacking can occur in the wild, accumulating unassessed combinations of transgenes even within a very short period of time (Hall et al. 2000; Warwick et al. 2008). Beyond that, there is a still largely unknown hybridization network to other members of the Brassicaceae family, involving bridge species (Eschmann-Grupe et al. 2003; Sobrino-Vesperinas 1988). From invasion biology it is known that plants can undergo an adaptation phase while they persist unrecognised before they expand in range and frequency (cp. Prentis et al. 2008).

The intention of this case study is to consider and accumulate potential causeeffect pathways to be studied in a plant context, which provides some differences compared to animal application of SPAGE techniques.

\section{Oilseed Rape-Biological and Ecological Characteristics}

Brassica napus is an allotetraploid combination of its two diploid parent species Brassica rapa and Brassica oleracea. As both wild parent species used to appear on the coasts of the Atlantic Ocean and the North Sea, several records suggest that 
amphiploid oilseed rape forms derived from the crossbreeding of B. rapa and B. olerace $a$ have occurred several times at different sites and with different forms of diploid parents (Song et al. 1990). Comparative genome analyses indicate that the diploid species B. nigra, B. rapa and B. oleracea are derived from hexaploid ancestors.

The oldest archaeological documented findings of oilseed rape in Europe date back to the thirteenth century. There is no evidence for a wild parental species of the crop (Chalhoub et al. 2014). It is assumed that Brassica napus has its origin in the Mediterranean, the common distribution area resulting in a B. napus geno- and phenotype have been exemplified (Körber-Grohne 1995). Due to its origin, B. napus is well adapted to the Mediterranean and central European climate conditions.

Although oilseed rape has characteristics of wild plants such as seed dormancy and adaptation of seed germination capacity to the annual cycle, it does not exist as a wild plant (Ammann and Vogel 1999). Janchen (1972), Adler et al. (1993) describe oilseed rape as largely cultivation dependent, although long-term persistence of feral populations has already been confirmed in several European countries (France: e.g. Pessel et al. 2001; Great Britain: e.g. Crawley and Brown 2004; Germany: e.g. Menzel 2006; Austria: e.g. Pascher et al. 2010; Netherlands: e.g. Tamis and De Jong 2010).

Besides feral oilseed rape which grows on landfills, along roadsides, and in ruderal sites, the so-called volunteer oilseed rape grows as a weed in fields in subsequent crop rotations. This is due to the oilseed rape's secondary dormancy allowing it to remain in the seed banks for multiple years. Up to twelve volunteer oilseed rape plants per $21.6 \mathrm{~m}^{2}$ were found by (Förster et al. 1998) on former oilseed rape fields in subsequent crops. Thus, volunteers represent an essential factor which needs to be considered in risk assessment of transgenic crop varieties (Pekrun et al. 1998). For instance, $70 \%$ of the oilseed rape seeds stored in the soil were still able to germinate after 1.5 years and up to $58 \%$ even after five years (Schlink 1998a, b, 1994). Due to the secondary dormancy, germination capacity can even be maintained for more than 10 years in deeper soil layers. Such high survival rates are otherwise achieved only by weed seeds (Mayer et al. 1995).

Oilseed rape as a di-genomic species possesses the complete genomes of its two parental species (Fig. 5.1). For this reason, various interspecific crosses with the parental species proved to be successful in the past (Chen et al. 1988; Gland 1982). Hybridisation of Brassica napus subsp. napus with other closely related species has been demonstrated several times (e.g. Kerlan et al. 1992; OECD 1997; Scheffler and Dale 1994). In order to successfully hybridise two species, the polyploidy level of the female plant has to be at least as high as that of the male pollen donating plant. Therefore, oilseed rape as a tetraploid plant often performs better as a pollen acceptor than as a pollen donor in hybridisation events with related diploid species (Harberd and McArthur 1980; Sikka 1940).

Allotetraploid hybridisation due to the double genome of oilseed rape increases the genetic variability which can occur in the resulting hybrids. Due to backcrossing with the parent species, new genes can be incorporated into the gene pool (introgression). 


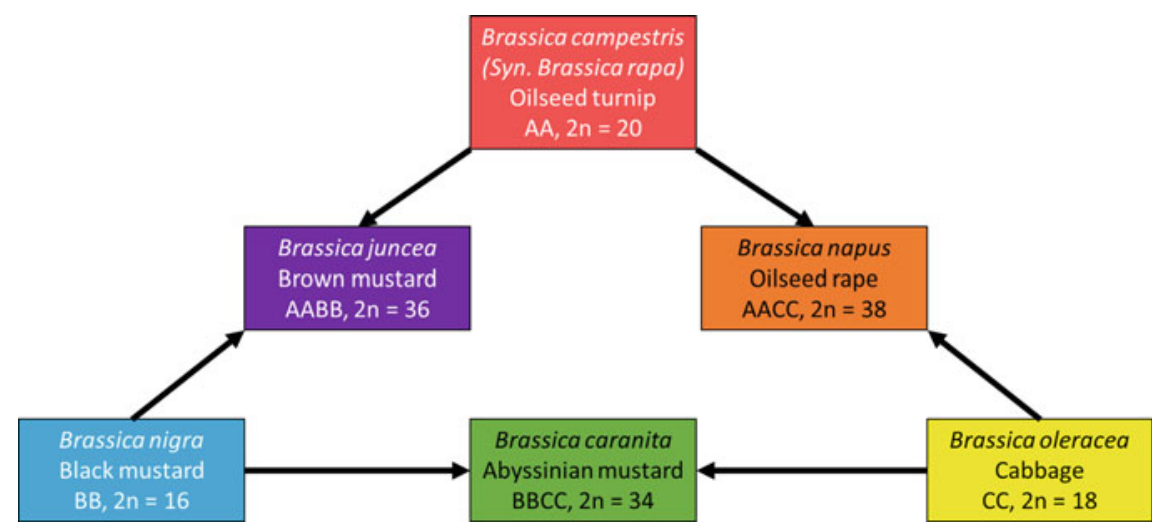

Fig. 5.1 Relations of selected diploid and alloploid members of the genus Brassica. Adapted from Nagaharu 1935

Profile: Oilseed rape, Brassica napus L. (Fig. 5.2).

Location: On agricultural land: under cultivation, and as a volunteer in subsequent crop rotations. As feral plants on landfills, along roadsides, on fallow land, former rapeseed fields. Mainly on fresh, nutrient- and alkaline sandy or loamy soils, deep soil with sufficient water supply.

Life form: annual to perennial.

Flower: In cultivation, the main flowering time of feral oilseed rape is between March/April to June. Outside cultivation, flowering extends to October, sometimes even later. Flowering usually lasts for about two to three weeks.

Fertilisation: Oilseed rape is self-compatible and high levels of self-pollination (up to $70-80 \%$ ) were described. Its brightly coloured petals, productive nectaries, the fragrance, the protogyny and the outwardly open anthers already indicate its potential for cross-pollination, which is conferred by insects; wind pollination also occurs and is responsible for pollen distributions over large distances up to $26 \mathrm{~km}$ (Ramsey et al. 2003).

Fruit: The fruits are up to $8 \mathrm{~cm}$ long and up to $4 \mathrm{~mm}$ thick, with a 1-2 $\mathrm{cm}$ long beak. At the time of the harvest, there are about 30-50 plants per square meter in the field. Each plant produces 7-10 lateral shoots and 120-200 pods.

Seeds: Each pod contains about 18-30 small, one millimetre large, spherical seeds. Plants produce more than 1000-1400 seeds. Thousand grain weight (TGW) is approx. $5 \mathrm{~g}$.

Germination: Germination is rapid and uniform. Seeds survive in the soil by secondary dormancy varies depending on the germination temperature, the light supply, the variety and the season. B. napus is frost resistant down to about -15 to $-20^{\circ} \mathrm{C}$.

Phenotypic plasticity: Depending on exposition, climatic conditions and nutrient supply, plants can considerably vary in height, branching and number of pods (between one single up to several hundreds.

(profile adapted from Breckling et al. 2004). 


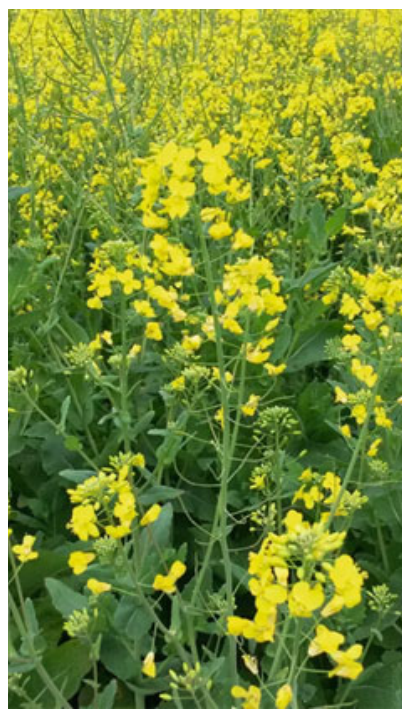

Fig. 5.2 Flowering oilseed rape

\section{Production, Uses and Genetic Modification}

Oilseed rape is one of the first crops of which genetically modified varieties were grown on a large scale. Multiple varieties with various properties, in particular herbicide resistance have been developed. Genetically modified oilseed rape varieties have been grown in the USA and Canada since 1996 (ISAAA 2017), and in Australia since 2008 (James 2015). In the EU, albeit there have been 383 field trials in 11 countries, ${ }^{1}$ there are so far only approvals for import of GM oilseed rape as food and feed, but not for commercial cultivation inside the EU. Table 5.1 lists the top rapeseed producing countries concerning the mass and area of cultivated rapeseed. If known, the estimated percentage of GM rapeseed is given.

Up until the 1970s, due to its high erucic acid and glucosinolate contents, oilseed rape could hardly be used for consumption. Since 1974, however, LEAR-varieties (low erucic acid rapeseed) with an erucic acid content below $2 \%$ became available. Developed in Canada, double low varieties with low erucic acid and almost no glucosinolate contents were bred by traditional means (canola). This allowed the increased use of the oil and seed protein feed for non-ruminating animals such as pig and chicken. Next to the widely cultivated double low varieties, HEAR-(high erucic acid rapeseed), HO-(high oleic acid), HOLLi-(High oleic, low linoleic), and triple-zero varieties exist. The latter in addition to the low erucic acid and glucosinolate contents, is also low in fibre content.

\footnotetext{
${ }^{1}$ https://gmoinfo.jrc.ec.europa.eu/overview-plants.aspx.
} 
Table 5.1 Top oilseed rape producers and cultivation areas in 2016 (FAOSTAT, ISAAA, USDA)

\begin{tabular}{l|l|l|l}
\hline Country & Produced rapeseed /tonnes & Cultivated area /ha & GMO Percentage \\
\hline Canada & $18,423,600$ & $7,990,300$ & $93 \%$ \\
\hline China & $15,281,624$ & $7,614,543$ & \\
\hline India & $6,797,000$ & $5,762,000$ & \\
\hline France & $4,727,961$ & $1,550,720$ & \\
\hline Germany & $4,579,600$ & $1,325,700$ & \\
\hline Australia & $2,944,000$ & $2,357,000$ & $23 \%$ \\
\hline Poland & $2,219,270$ & 826,946 & \\
\hline United Kingdom & $1,775,000$ & 579,000 & \\
\hline United States & $1,403,650$ & 686,440 & $90 \%$ \\
\hline Czech Republic & $1,359,125$ & 392,991 & \\
\hline Romania & $1,292,779$ & 455,048 & \\
\hline Ukraine & $1,153,910$ & 449,930 & \\
\hline Russia & 998,932 & 911,849 & \\
\hline Hungary & 608,700 & 222,085 & \\
\hline
\end{tabular}

Oilseed rape has a wide range of applications such as cooking oil, ingredient of cosmetics but also pesticides, biofuels, etc. It is the third-largest used source of vegetable oil in the world (USDA 2018) followed by soybeans and oil palms (Kumar et al. 2007; Langhof and Rühl 2017).

\section{Potential Hybridisation Partners}

Besides oilseed rape's capability to persist in the seed bank and re-emerge either as feral or volunteer, the plant also has multiple potential hybridisation partners. With decreasing likelihood of hybridisation according to a study in Austria (Pascher et al. 2000), these are:

Turnip

Cabbage

Longstalked rape

Brown mustard

Black mustard

Haddick

Wild mustard

White mustard

Perennial wall-rocket

Annual wall-rocket

Radish
Brassica rapa (feral): partental species

Brassica oleracea (feral): parental species

Brassica elongata

Brassica juncea

Brassica nigra

Raphanus raphanistrum

Sinapis arvensis

Sinapis alba

Diplotaxis tenuifolia

Diplotaxis muralis

Raphanus sativus 


$\begin{array}{ll}\text { Garden rocket } & \text { Eruca sativa } \\ \text { Watercress dogmustard } & \text { Erucastrum nasturtiifolium } \\ \text { Hairy rocket } & \text { Erucastrum gallicum } \\ \text { Steppe cabbage } & \text { Rapistrum perenne } \\ \text { Shortpod mustard } & \text { Hirschfeldia incana (formerly Brassica geniculata) } \\ \text { Annual bastardcabbage } & \text { Rapistrum rugosum } \\ \text { Austrian hare's ear mustard } & \text { Coringia austriaca } \\ \text { Oriental hare's ear mustard } & \text { Conringia orientalis } \\ \text { Tatarian cabbage } & \text { Crambe tataria (endangered species in Austria, only } \\ & \text { one location of occurence) } \\ \text { Hedge mustard } & \text { Sisymbrium spp }\end{array}$

Additional species for single European countries are listed in Chévre et al. (2004). A study from Belgium (Devos et al. 2009) established a gene flow index to evaluate the introgessive hybridisation potential (IHP) of each relative. They conclude that Brassica rapa as one of the parents of oilseed rape has the highest introgressive hybridisation propensity (IHP value $=11.5$ ), followed by Hirschfeldia incana and Raphanus raphanistrum (IHP = 6.7), Brassica juncea $(\mathrm{IHP}=5.1)$, Diplotaxis tenuifolia and Sinapis arvensis (IHP $=4.5)$, in Flanders.

The following paragraphs take a closer look at some of the well-documented hybridisation partners of oilseed rape most common in Germany.

\section{Oilseed turnip (Brassica rapa)}

Brassica rapa is not only a highly developed crop but also one of the oldest crops that was grown by man. B. rapa ssp campestris is the wild form of todays cultivated turnip, a breeding source of a variety of crops. Compared to oilseed rape, turnip (Fig. 5.3) has some morphological differences (Fischbeck et al. 1982). Since B. napus (AACC) is an allotetraploid descendant of B. rapa (AA) and B. oleracea (CC), spontaneous interspecific hybridisation between oilseed rape and turnip occurs frequently. Spontaneous crosses have been observed under natural conditions, among others by Stace (2010). Successful hybridisation has also been proven under controlled as well as under field conditions in different countries: Canada, England, Denmark, New Zealand, Australia, Czech Republic, (Bing et al. 1991; Jørgensen et al. 1996; Jørgensen and Andersen 1994; Metz et al. 1997; Mikkelsen et al. 1996; Scott and Wilkinson 1998).

Hybridisation is most successful when oilseed rape functions as the female parent (Scheffler and Dale 1994), but crossings in both directions are possible (Becker 1951). Jørgensen and Andersen (1994) could show an interspecific hybridisation rate of 9-93\% in crossbreeding of Brassica napus and Brassica rapa. In hybridisation experiments between oilseed rape and turnip it was found that all $\mathrm{F}_{1}$-hybrids were morphologically similar to oilseed rape, but showed a reduced pollen fertility of around 55\% (Warwick et al. 2003). The introgression rate of herbicide resistance genes from oilseed rape to turnip was observed to be low (Hansen et al. 2001; Jørgensen 1999; Norris and Sweet 2002). Interspecific hybrids are able to backcross with B. rapa as a female parent (Jørgensen et al. 1996; Mikkelsen et al. 1996). 


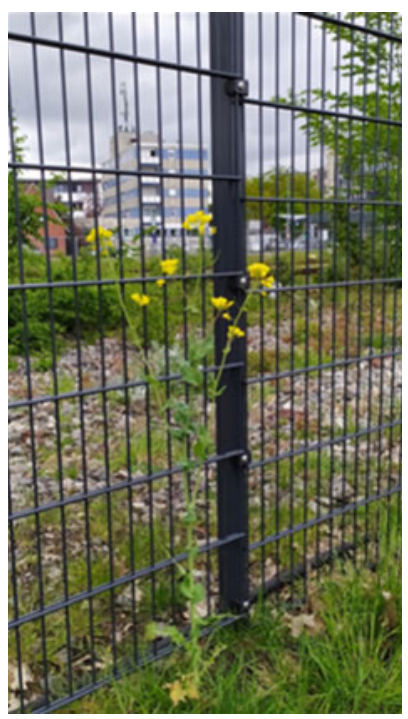

Fig. 5.3 As one of the most significant hybridization partners, Brassica rapa also occurs outside cultivation at feral sites (Vechta 2019)

\section{Haddick (Raphanus raphanistrum)}

The haddick, also called wild radish, is native to Europe, Western Asia and parts of Northern Africa. It is considered a wide-spread and invasive weed that grows in summer crops, former oilseed rape fields but also in urban environments and along roads. Raphanus raphanistrum shows a great morphological variability. Seeds of haddick remain viable in the soil for a long time due to a restistant seed coat (Darmency et al. 1998).

Already in 1924, intergeneric hybrids between the more distantly related genera Raphanus and Brassica have been successfully produced (Karpechenko 1924). Transgenic oilseed rape hybrids can also be created by ovary culture (Kerlan et al. 1993). Under natural conditions successful hybridisation was detected between male sterile specimens of B. napus and R. raphanistrum (Eber et al. 1994). In that experiment, frequent chromosome pairing and the presence of multivalent compounds have indicated that recombination is also possible between the chromosomes of different genomes. The recombination between the genomes of B. napus and R. raphanistrum could also be shown experimentally (Baranger et al. 1995).

Spontaneous hybridisation of oilseed rape and haddick, even under natural field conditions, was achieved at a relatively high frequency in France (Darmency et al. 1998) and Australia (Rieger et al. 2001). Intergeneric gene flow may occur mainly through introgression of the transgene into the genome of the weeds (Chèvre et al. 1997).

The hybrid frequency is expected to range between 0.006 and $0.2 \%$ of the total seeds produced (Darmency et al. 1998). In male sterile oilseed rape plants surrounded 
by haddick, even up to 37 hybrids per plant could be detected. Seed production of the $F_{1}$ and $F_{2}$ generations even reached rates of $0.4-2 \%$ in comparison to wild haddick.

In contrast, Australian studies on gene flow between oilseed rape and haddick showed low hybridisation rates $\left(<4 \times 10^{-8}\right)$. When haddick acted as the maternal partner, no hybrids were detected (Rieger et al. 2001).

Perennial wall-rocket (Diplotaxis tenuifolia) and Annual wall-rocket (Diplotaxis muralis).

The genus Diplotaxis encompasses around 30 species. Diplotaxis is spread across the warmer West Eurasian as well as in the East African mountains. Its centre of diversity lies in the south-western Mediterranean area (Eschmann-Grupe et al. 2003).

Diplotaxis tenuifolia occurs in moderately dry ruderal areas, which can be found especially in harbour areas, on railways or increasingly in urban areas but also in farmland. It is one of the four species in Austria with the highest hybridisation probability with oilseed rape due to the close genetic relationship and the frequent occurrence (Pascher et al. 2000). Hybridisation events with oilseed rape were reported by Ringdahl et al. (1987). Similar to Diplotaxis muralis, hybridisation with oilseed rape as a female parent was unsuccessful (Salisbury 1989). The crossing between D. muralis and D. tenuifolia produced a successful $\mathrm{F}_{1}$-generation (Eschmann-Grupe et al. 2003; Sobrino-Vesperinas 1988), so hybridisations with Diplotaxis sp. and oilseed rape might also create viable hybrids via such "bridges".

D. muralis prefers moderately dry soils and can be found on short-lived weed fields and, as the name implies, close to walls. In a crossing experiment by Ringdahl et al. (1987), a total of 285 flowers of 9 Diplotaxis plants were pollinated with oilseed rape pollen. 157 pods $(60.1 \%)$ with 607 seeds were formed, $31(5.1 \%)$ of these seeds were hybrids(Ringdahl et al. 1987). In Australia, Diplotaxis muralis produces viable but sterile hybrids after forced pollination with oilseed rape pollen. The cross yielded 0.054 seeds per pollinated flower (Salisbury 1991). In contrast to the results of (Salisbury 1989) attempts of hybridisation with oilseed rape as a female parent produced hybrids in studies by Bijral and Sharma (1996).

\section{Conclusions on Gene Flow Potential}

There are numerous, widely distributed hybridisation partners with a high level of cross-fertilisation within the Brassicaceae family-almost exclusively among the species of the tribe Brassiceae-which makes the formation of intra- and interspecific hybrids quite common (Chèvre et al. 2004). Large-scale cultivation of transgenic oilseed rape over several years supports the formation of hybrids and thus the propagation of transgenes. It can establish feral populations at ruderal sites and occasionally even in natural habitats such as river banks (Pascher et al. 2000, 2017; Pascher and Gollmann 1999). Also, the persistence of oilseed rape seeds in the soil is an essential factor. There are various studies with different results concerning the 
distribution of pollen or hybridisation frequencies of related crossing partners of oilseed rape. For instance, the outcrossing rates of the same plant species differ by several orders of magnitude in different experiments. Furthermore, the frequency of naturally occurring gene transfer varies to a large extent not only between plant families and species, but also between populations, individuals and even from year to year, hinting at the importance of the current environmental conditions such as temperatures and moisture during 'pollen rain', wind force and direction, size of donor and receiver population, distance etc. or different test setup (e.g. Gliddon 1999).

Finally, knowledge about distribution, abundance and flowering times of single relevant species are indispensable. In the GenEERA project (2001-2004), the cultivation sites of oilseed rape and the co-occurrences of potential hybridisation partners in the vicinity was assessed and quantified in maps and geostatistically evaluated for typical Northern German landscapes and an urban area, the city of Bremen. Figure 5.4a shows the cultivation situation. Figure 5.4b indicates the approx. $500 \mathrm{~km}^{2}$ that were visited in all publicly accessible areas to map the number of oilseed rape single plants and populations as well as its potential hybridisation partners.

\section{Pests and Pathogens}

As the Brassica species are important native components of many ecosystems in temperate climate, they provide forage for a large number of invertebrates and several other organisms such as mice and birds (Organisation for Economic Co-operation and Development OECD 2012). Herbivory is an important limiting factor in the commercial crop production of Brassica species (Kimber and McGregor 1995; Lamb 1989).

Oilseed rape is also targeted by a wide range of pathogens, bacterial, fungal, viral, phytoplasmal, and miscellaneous other diseases. Three diseases are particularly dangerous, because they are pandemic and have a potential for major crop injury. These fungal diseases are blackleg, also known as stem canker, Sclerotinia stem rot and clubroot. The conventional development of resistant varieties is difficult due to the multi race pathogenicity (Organisation for Economic Co-operation and Development OECD 2012).

\section{Pollen Transfer and Gene Flow}

Oilseed rape fields produce pollen for about three weeks, depending on the particular weather conditions. Brassica napus is self-fertile. But since the stigma is mature around three days before and after the anther, cross-pollination is also well possible. Therefore, seed formation mainly consists of a mixture of cross- and self-pollination of variable ratios. The ratio of cross fertilisation depends on various factors such as the weather at the time of flowering and the genetic predisposition of the lineages 
5 Case Study 2: Oilseed Rape (Brassica napus L.)

(a)

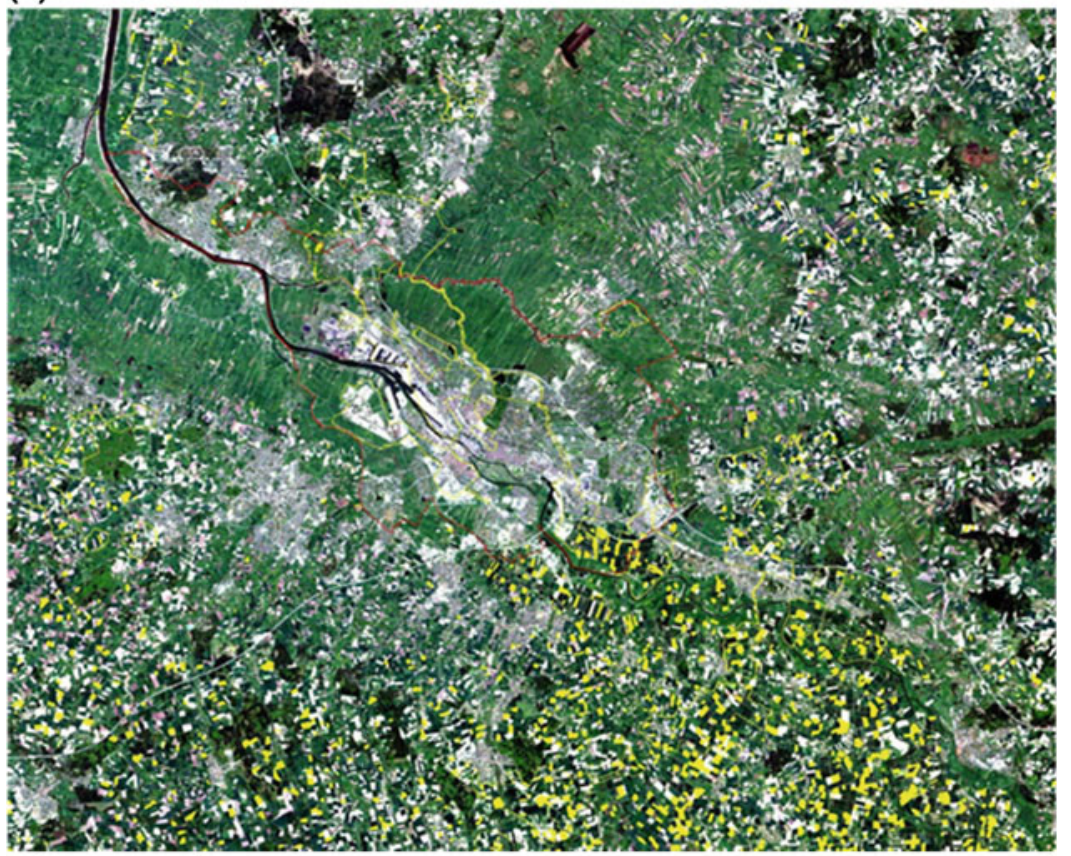

(b)

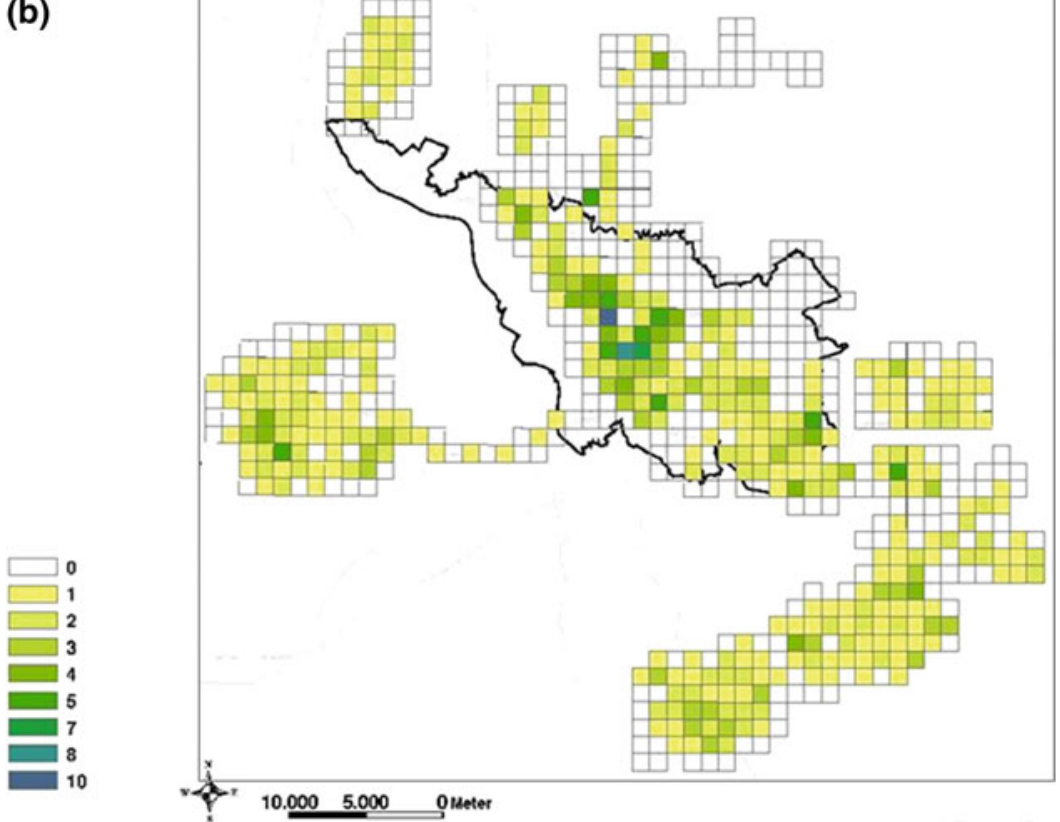


4Fig. 5.4 a Satellite image of the surroundings of Bremen (Landsat) from May 2001. Oilseed rape fields are marked in yellow. The border of Bremen is indicated as a thin red line. Areas visited during the field survey are surrounded by a yellow line. From: (Menzel and Born 2004, p. 43). b Number of hybridisation partners mapped during the field survey in 2001. Solid Black line: Bremen city limit. Light grey lines: Main traffic axes. The colour code refers to the number of species (oilseed rape and hybridisation partners) found in the respective grid element $\left(1 \mathrm{~km}^{2}\right)$. It is apparent that the central urban region harbours the highest species number of the considered plant group. From: Menzel and Born (2004, p. 31)

(Hühn and Rakow 1979). Exact details of the quantitative effect of individual factors are not available in the literature and the estimates for self- and cross-pollination vary greatly. For instance, Hühn and Rakow (1979) assume that self-pollination accounts for an average of two-thirds of oilseed rape. Timmons et al. (1995) reported outcrossing rates of $5-55 \%$ based on various data from the literature under field conditions. Neemann and Scherwaß (1999) assume an average cross-fertilisation rate of 20-30\%. Other authors report the outcrossing rate in rapeseed to be 5-30\% (Rakow and Woods 1987), 22-36\% (Scheffler et al. 1993) or 41\% (Lavigne et al. 1998).

Oilseed rape pollen is more or less spherical with a diameter of $25 \mu \mathrm{m}$. Their size corresponds approximately to the size of many fungal spores, which are distributed primarily by wind (McCartney and Lacey 1991). A yield reduction of 33-50\% in oilseed rape flowering under windless conditions in a greenhouse experiment suggests that wind also plays a role in the pollination of oilseed rape, especially for long distance dispersal (Timmons et al. 1995). Furthermore, it is reported that good yields can be achieved even in the absence of insects (Wilkinson et al. 1995). The attractive flowers of oilseed rape are mainly pollinated by insects, honey bees play a significant role in pollination (Gerdemann-Knörck and Tegeder 1997). To secure purity of the varieties in seed production, isolation distances of $100 \mathrm{~m}$ for certified seed and $200 \mathrm{~m}$ for basic seed are required in the EU (Ingram 2000). In Austria, although several international scientists suggest an isolation distance of $4 \mathrm{~km}$ considering $26 \mathrm{~km}$ as maximum investigated confirmed pollen dispersal distance (Ramsey et al. 2003), isolation distances of only $200 \mathrm{~m}$ for lineage varieties and $500 \mathrm{~m}$ for hybrid varieties are put in practice (Pascher and Dolezel 2005). The aim of this measure is not an absolute avoidance of gene flow, but a limitation as efficient as possible.

Pollen transport depends on various factors such as the respective lineage, the location and season (Raybould and Gray 1993). Also, seed spillage is a significant factor, since on the one hand large amounts of seed loss occur during harvest of oilseed rape are lost in the field [30-40 kg/ha (Gerdemann-Knörck and Tegeder 1997)]. Because of the small seed size seeds are regularly spilled during transport and handling activities (Adolphi 1995; Crawley et al. 1993; Franzaring et al. 2008; Pascher et al. 2017; Warwick 1997).

These circumstances lead to an almost ubiquitous occurrence of oilseed rape in the farmland and to the situation that oilseed rape plants combine the characteristics of different oilseed rape lineages or varieties. For genetically modified varieties, (Hall 
et al. 2000) described the occurrence of plant individuals with multiple herbicide resistances in a location where varieties with different single resistances were grown. In this case, the triple resistant individuals were detected up to a distance of $550 \mathrm{~m}$ from the putative pollen source.

\section{Gene Flow by Airborne Pollen Transport}

Although information on the spread of oilseed rape pollen exists, there are no quantitative data on the proportions or the respective influencing factors available in the literature. However, a large number of influencing factors (Ingram 2000; Treu and Emberlin 2000) as well as optimal conditions for high and low outcrossing rates (Feil and Schmid 2001) are compiled. It is estimated that under typical weather conditions in Britain (wind speed of $2 \mathrm{~m} / \mathrm{s}$, with convection currents), a potential pollen drift of almost $172.8 \mathrm{~km}$ is possible within $24 \mathrm{~h}(7.2 \mathrm{~km} / \mathrm{h})$. Even a pollen transport over $864 \mathrm{~km}$ would be possible within one day with wind speeds of $10 \mathrm{~m} / \mathrm{s}$. Therefore, it is not surprising that pollen can be detected in the air above the middle of the Atlantic Ocean (Treu and Emberlin 2000). However, only a small amount of the released pollen drifts and no quantitative data on the long distance spread of pollen is available. Factors influencing the quantity of pollen accredited to regional gene flow may be the type of plant and variety characteristics, the current weather conditions (particularly wind conditions) and the time of pollination, especially the time of the day. For example, at night, there are different conditions for pollination than during the day. At night, the long-distance transmission of pollen (regional gene flow) is usually lower (McCartney and Lacey 1991).

Furthermore, the landscape configuration has a dominant influence on the extent of local gene flow between crops and wild relatives (Squire et al. 1999). The rate of crossbreeding from more distant sources is higher when there are no local pollen sources. The highest pollen concentrations occur on days with intense insolation and strong wind (McCartney and Lacey 1991). Correspondingly, a reduction in the amount of detected oilseed rape pollen to $1.4 \%$ compared to the previous year was attributed to heavy rainfalls and high humidity in the second year (Scott 1970 referenced by Treu and Emberlin 2000). With the two factors humidity and more significantly the wind, a correlation to the pollen concentration but not to the relation between wind speed and distance could be found. Instead, it is suspected that upward air movements are crucial for the pollens' trajectory (compare viable maize pollen in $1.8 \mathrm{~km}$ height), while wind speeds play a minor role (Feil and Schmid 2001). Moreover, the main wind direction plays a major role. Messeguer et al. (2006) assessed the influence of wind for maize cross-pollination. 


\section{Lineage-Specific Factors of Actual Gene Flow}

Beside the factors that influence potential gene flow, the actual entry of pollen into plant populations (actual gene flow via pollen) are influenced by additional factors. These factors are also dependent on the oilseed rape lineage such as flowering periods of donor and receptor populations, outcrossing rates, self- and cross-fertilisation rates, hybridisation rates, pollen life-span and morphological characteristics regarding the compatibility of pollen and stigma.

Outcrossing rates observed in fertile oilseed rape are not transferable to male sterile oilseed rape used for hybrid seed production. Conversely, observations with male sterile recipients or those incapable of self-fertilisation cannot be transferred to male fertile of self-pollinating populations (Ingram 2000).

Hybrid varieties, such as Synergy, appear to be particularly prone to introgression (Simpson et al. 1999), as they worked with male sterile plants and the cultivated crop regularly contained male sterile plants. However, in some hybrid varieties, fertility in the growing crop is mostly restored (not always completely), so foreign pollen in turn has to compete with local pollen (Ingram 2000).

\section{Not-Lineage-Specific Factors of Actual Gene Flow}

The following factors influence the competitive situation between the pollen of the receptor population and 'foreign' pollen. This competitive relationship is a significant factor which pollen fertilises the flowers of the receptor population. These factors are the geographic distance to plants and receptor populations, crop density and size ratio of donor to receptor populations (Feil and Schmid 2001) as well as competition between own and foreign pollen arrived at the stigma and growing towards the ovary.

\section{Gene Flow via Pollen Transport by Insects}

Insects play the most important role in the fertilisation of oilseed rape. Some farmers even pay beekeepers to set up beehives near their fields. This is of special importance for sterile hybrid crops (Ramsey et al. 1999) which, for instance, account for approximately $75 \%$ of the oilseed rape varieties in Austria. All of the GM oilseed rape varieties are hybrids. The relatively high sugar concentration in the nectar of the plant attracts bees and other insects over long distances (Ramsey et al. 1999; Saure et al. 1999a, b). Honey bees provide $90 \%$ of insect pollination in oilseed rape (Mesquida et al. 1988). However, solitary bees and bumblebees, if they occur, are comparably efficient in pollination. Other species such as dipterans, butterflies and beetles occur less frequently and have a lower pollination performance (Mesquida et al. 1988; Saure et al. 1999a, b). 
Information on insect flight distances vary greatly. The data on the flight distances of honey bees range from $600 \mathrm{~m}$ (Osborne et al. 1999) over 2 or $5 \mathrm{~km}$ ( according to beekeepers) and 2.75 and 4.6 miles (4.42 and $7.4 \mathrm{~km}$ ) (Eckert 1933) up to $14 \mathrm{~km}$ (Saure et al. 1999a, b). Clustering radii of up to $6 \mathrm{~km}$, which would correspond to an area of up to $100 \mathrm{~km}^{2}$ around a hive were observed (Waddington et al. 1994). For solitary bees with a small body size, flight distances of $200 \mathrm{~m}$, up to $800 \mathrm{~m}$ for sand bees, and $2 \mathrm{~km}$ for bumblebees were measured (Saure et al. 1999a, b). Bees can carry up to 60,000 oilseed rape pollen on their body in addition to the pollen in their pollen sacs. In the hive, worker bees clean each other. Thereby, pollen transfer to other bees takes place. Thus, bees leaving the hive probably carry a mixture of fertile pollen on their bodies (Ramsey et al. 1999).

In summary, the high variability concerning data on the flight activity of insects also have an unpredictable influence on gene flow. Insect activity is reduced during cold, wet, cloudy and stormy weather. Reduced insect activity is also observed during an especially hot and dry year (Brown and Brown 1996).

The extrapolation from small- to large-scale experiments is considered as difficult. For instance, a small pollen source experiment extrapolated $2-11 \%$ of the original pollen level $100 \mathrm{~m}$ from the pollen source. But a large-scale study showed pollen densities of 27-69\% at $100 \mathrm{~m}$ distance from an oilseed rape field (Timmons et al. 1995; Wilkinson et al. 1995). Therefore, the extrapolation from small pollen sources to the field level is problematic (Wilkinson et al. 1995). However, small-scale experiments yield valuable results, if the gene flow from or into small stocks is considered. Prime examples for this would be feral oilseed rape populations also descending from transport losses as well as volunteer populations.

\section{Seed Persistence and Germination in Oilseed Rape}

Apart from B. napus capability to spread its genetic material by pollen, also volunteers acting as transgene donors due to seed persistence have to be considered. It is argued that the risk of spread of e.g. the pat-gene (glufosinate resistance gene) by threshing losses at harvest and volunteering in the next cultivation cycle is much higher than by pollen transport (Fischbeck 1998). Therefore, the seed persistence of oilseed rape plays a major role in its gene flow pattern. Thereby, not only the persistence over time but also the spatial distribution of seeds has to be taken into account.

In oilseed rape fields, on average $200-300 \mathrm{~kg}$ of grain per hectare remain after harvest (Pekrun et al. 1998). Whereas, the optimal sowing rates are as low as 6090 seeds $/ \mathrm{m}^{2}$ (Männer 2000). In Northern Germany, however, occurrence of 400 volunteers $/ \mathrm{m}^{2}$ is not uncommon (Gerdemann-Knörck and Tegeder 1997). In Southern Germany, 0-202 seeds $/ \mathrm{m}^{2}$ were observed one to six years after oilseed rape cultivation. Whereby, seed counts above 100 occurred only at locations, where unusually large quantities of lost oilseed rape were left on the field due to late harvesting or hail (Roller et al. 2001). Other studies even report 10,000 lost seeds $/ \mathrm{m}^{2}$ (Lutman 1993). This amount of persistent seeds has an apparent impact on volunteer emergence. 
Norris et al. (1999) observed that in the United Kingdom, the number of volunteer plants can vary greatly from one area to another. This depends on details of the agricultural practice.

For instance, it was observed that an erucic acid content of less than two percent was achieved only seven years after a switch to an erucic acid free oilseed rape variety (Sauremann 1987) referenced by (Schlink 1994). Also, a growth of oilseed rape varieties cultivated ten years ago could be found (Röbbelen 1986) referenced by Schlink (1994). It could be shown in experiments that after ten years on average $0.5 \%$ of the buried seeds survived. The maximum survival was $4.7 \%$. Of those persistent seeds, over $96 \%$ sprouted and developed viable seedlings within four days after being exposed to daylight on the soil surface (Schlink 1998b).

These high persistence probabilities of above $70 \%$ over a one-and-a-half-year period and nearly $60 \%$ after five years in the soil resemble those of weed seeds. Also a change in the germination rate in the annual cycle is more characteristic for wild plants (Pekrun et al. 1997). Due to the traits of his two wild parental species, oilseed rape has maintained 'weedy' characteristics (Schlink 1994).

The long-term survival of $B$. napus seeds and resulting volunteers is attributable to dormancy. Dormancy grants seeds the ability to survive for extended periods of time in the soil also under changing environmental conditions. Seeds are defined to be dormant, if they do not germinate under the optimum environmental conditions and an additional factor or environmental stimulus is required for germination. There is a distinction between primary and secondary dormancy. The primary dormancy prevents germinations on the mother plant and up to a certain period of time after the seed has dropped. Secondary dormancy on the other hand, is induced by unfavourable environmental conditions on the swollen seeds and can either be broken by specific environmental stimuli or degraded over a longer time period. Thereby, a clear distinction between primary and second dormancy is not always possible and dormancy should not be confused with quiescence. Quiescence happens, when seeds do not germinate as a result of adverse environmental conditions e.g. lack of water, air or due to unfavourable temperatures. Influencing factors for germination and survival are listed in Table 5.2.

\section{Genetic Modifications in Oilseed Rape}

Oilseed rape is one of the first crops that were genetically modified. Several varieties were tested, deliberately released and commercialised. Most of them confer herbicide resistances to a number of active ingredients, among of which glyphosate, glufosinate, bromoxynil and others. Also varieties with altered plant metabolism, in particular fatty acid composition, and male sterility have been created. Moreover, Bt-Insect toxicity (Halfhill et al. 2002) as well as growth form (Gressel 1999; Reuter et al. 2008), and various other traits have been tested so far. A survey of genetic modifications, including oilseed rape is provided by the Food and Agriculture Organisation 
Table 5.2 Factors that influence seed survival and germination

\begin{tabular}{l|l}
\hline Seed survival influencing factors & Seed germination influencing factors \\
\hline Variety characteristics & Variety characteristics \\
\hline Year of the seed burial & Time of the year \\
\hline Storage duration in the soil & Storage duration in the soil \\
\hline $\begin{array}{l}\text { The depth at which the seed is stored in the } \\
\text { soil }\end{array}$ & Water supply \\
\hline Soil conditions & Soil conditions \\
\hline Habitat & Temperature \\
\hline Storage temperature before storage in the soil & Light availability \\
\hline $\begin{array}{l}\text { Duration of stress factors } \\
\text { (see Pekrun, Lutman et al. 1997b) }\end{array}$ & $\begin{array}{l}\text { Short-term light exposure while Otherwise in } \\
\text { darkness }\end{array}$ \\
\hline $\begin{array}{l}\text { Amplitude in temperature changes } \\
\text { (see Pekrun Lutman et al. 1997b, c) }\end{array}$ & Stratification \\
\hline Age of the seeds & Drying \\
\hline
\end{tabular}

of the United Nations $\left(\mathrm{FAO}^{2}\right)$, by the Biosafety Clearing House mechanism of the Biosafety Convention (Cartagena Protocol ${ }^{3}$ ) and for deliberate release and placing on the market of GMO by the Joint Research Centre of the European Union. ${ }^{4}$

\section{Persistence of Genetically Modified Oilseed Rape Outside Fields}

Breckling and Menzel (2004) discussed the following implications in the light of transgenic oilseed rape persistence. They discuss general implications, effects on agriculture and cultivation implications and effects on biodiversity and wildlife.

\section{General Implications}

If no additional fitness differences occur, (Breckling and Menzel 2004) conclude, transgenic oilseed rape would be likely to disperse as widely as conventional varieties with regard to the ecological and physiological characteristics of the species. Wild

\footnotetext{
${ }^{2}$ https://www.fao.org/food/food-safety-quality/gm-foods-platform/en/, https://www.fao.org/food/ food-safety-quality/gm-foods-platform/browse-information-by/commodity/commodity-details/ en/?com=38947.

${ }^{3}$ https://bch.cbd.int/database/organisms/default.shtml, https://bch.cbd.int/database/results? searchid $=742060$.

${ }^{4}$ https://gmoinfo.jrc.ec.europa.eu/Default.aspx, https://gmoinfo.jrc.ec.europa.eu/gmp_browse. aspx.
} 


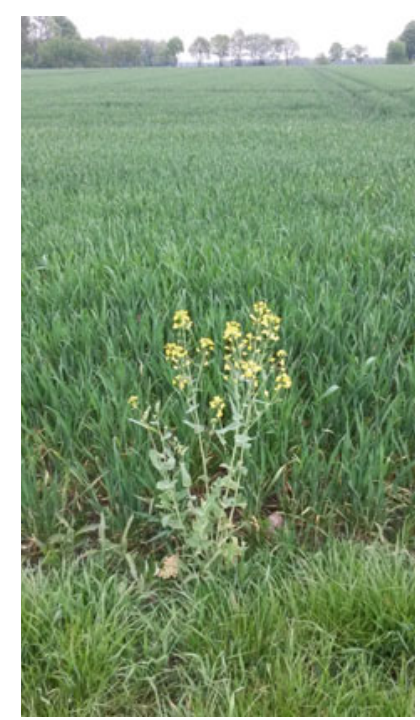

Fig. 5.5 Escape from cultivation: single oilseed rape plant growing on the margin of a cereal filed in Goldenstedt, Lower Saxony (Germany) 2017

populations of B. napus receive a steady input due to seed losses from cultivation, seed transport by vehicles, animals (e.g. wild boar) or man. Buried seeds from the soil seed bank eventually emerge when soil substrate is transported and redeployed. All these factors support sustaining of feral populations. Based on the empirical observation, that urban feral sites are important as centres of occurrence for oilseed rape as well as for potential hybridisation partners (Menzel 2006, see also Fig. 5.5), It is argued that the conditions for genetic interaction (i.e. cross-pollination) are largely provided not only in rural but also in urban environments. The conditions for a fixation of genetic traits seem even more favourable in urban environments due to the smaller population sizes (Klinger and Ellstrand 1994). Since oilseed rape frequently grows along traffic axes and seeds are transported attached to car tires, a rapid translocation seems possible. If an invasive potential should be acquired, cars would strongly contribute to large distance transport. von der Lippe and Kowarik (2007) demonstrated this in an empirical investigation.

\section{Agricultural Implications}

Concerning agricultural implications, it is argued that the introduction of transgenic, herbicide resistant varieties would require important changes of the general agricultural practice, for GMO growers and neighbouring conventional fields. Considering the issue of the pesticide treadmill, (Breckling and Menzel 2004) state that due to the 
fact that harvest seed losses occur on the field to a large extent (Cramer 1990), herbicide resistance will lose efficiency in volunteer control leading to a reduced number of active herbicide compounds available for weed management and volunteer control. They further elaborate that since pollen transfer is efficient over large distances (Treu and Emberlin 2000), cross-pollination-conferred GM-contamination of neighbouring fields regularly occurs. Thus, seed losses in subsequent generations could cause weed management problems, even if the level of contamination may remain below the legal threshold (Pekrun 1994). Tracing the origin of crop contamination to a specific grower might not always be possible, even if the event (the specific variety) and thus the patent holder can be identified through genetic analysis. For Central European cultivation conditions at least, the gain of transgenic herbicide resistances is low (Augustin et al. 1998). As soon as oilseed rape has reached a certain height, it can usually outcompete weeds. Thus, Breckling and Menzel (2004) conclude that in oilseed rape cultivation, weed control before crop germination is usually sufficient and later herbicide treatments are rarely required. This applies to Central Europe; in other regions it may be different. Here, the small advantage in cultivation would have to outweigh the substantial cost for other growers as well as for the general public to cover the management system and documentation and damage regulation cost as well as separate conventional and transgenic processing and commodity flows. This may be one of the reasons, why transgenic varieties are not admitted for cultivation in the EU up to now.

\section{Conservation Implications}

As the fixation of transgenes in feral populations appears to be rather probable, conservational issues are implied. In reference to the concept of "genetic swamping" (Snow 2002) which addresses the threat of cultivation-specific, fitness altering genes to wild type populations, Breckling and Menzel (2004) coined the term "transgenic swamping" which refers to transgenes escaping to feral populations. This seems inevitable in the case of oilseed rape. The impact of persisting transgenes on biodiversity is difficult to estimate. However, the invasive potential of released plants has been discussed previously (Hurka et al. 2003) and applications of the precautionary principle are in place also to prevent harm to biodiversity as a protected ecological good. Breckling and Menzel (2004) argue that in the light of the centre of biodiversity of oilseed rape being located in Europe and due to the inevitability of the transgene escape from cultivation to feral populations (Fig. 5.5), an unpredictable high number of genotypes would be anticipated. 


\section{Detection of Unintended Spread of Transgenic Oilseed Rape in Various Countries}

The following section summarises data collated by Testbiotech (Bauer-Panskus et al. 2013). Testbiotech imposingly evidences the uncontrolled and unintended spread and outcrossing of transgenic oilseed rape varieties for six countries.

Canada

Canada is one of the countries that grows herbicide tolerant oilseed rape in large quantities. Transgenes were found in nearly all of the conventional Canadian oilseed rape seed supply (Friesen et al. 2003). Feral populations had developed at the edges of fields and along roadsides. In the province of Manitoba, $88 \%$ of feral oilseed rape populations examined contained glyphosate tolerant plants. About $50 \%$ of the plants were tolerant to both herbicides, imidazoline and glufosinate (Knispel et al. 2008). 93 out of 100 feral oilseed rape plants along field edges or roadsides tested, contained transgenic constructs (Knispel and McLachlan 2010). All feral populations tested in another study contained hybrids with Brassica rapa (Simard et al. 2006). Tests revealed that nearly no fitness costs are associated with the stacking of transgenes in oilseed rape plants (Simard et al. 2005). Persistence of such hybrid populations over time was affirmed by a long term survey which showed that feral hybrid populations of B. napus $\times$ B. rapa, despite a decreased fitness, persisted over six consecutive years (Warwick et al. 2008). Also transgenic volunteers could be found up to seven years after the original cultivation (Beckie and Warwick 2010).

\section{USA}

In the United States, commercial cultivation of genetically engineered oilseed rape started early and, at present, accounts for more than $90 \%$ of all oilseed rape fields. Unintended large scale dispersal of herbicide-tolerant oilseed rape along roadsides was demonstrated in North Dakota (Schafer et al. 2011). Out of all oilseed rape plants growing along roadsides, $80 \%$ tested positive for genetic modification. Of these plants one half contained the cp4epsps-gene for glyphosate tolerance, the other half the pat-gene encoding a tolerance to glufosinate. Some plants were tolerant to both herbicides.

Japan

Japan itself does not cultivate but imports genetically modified oilseed rape. The first studies on the presence of transgenic oilseed rape in ruderal habitats in Japan were published in 2005 (Saji et al. 2005). In the proximity of ports like Kashima, Chiba, Nagoya and Kobe as well as along transportation routes to industry plants where oilseed rape seeds are processed, plants were found that proved to be resistant to glyphosate or glufosinate although these transgenic varieties have never been cultivated. Feral oilseed rape populations co-occur with wild populations of $B$. juncea in port areas (Kawata et al. 2009). Transgenic oilseed rape plants were detected that had 
hybridised with each other and consequently, were tolerant to both herbicides (Aono et al. 2006). In follow-up studies feral populations were found along further transportation routes (Nishizawa et al. 2009) and in areas close to all other major ports (such as Shimizu, Yokkaichi, Mizushima, Hakata, or Fukushima) (see for example Kawata et al. (2009). Mizuguti et al. (2011) came to the conclusion that the investigated oilseed rape populations were able to self-sustain over time. In 2008 in the proximity of Yokkaichi port, $90 \%$ of all tested plants proved to be genetically modified. Also in that area, the first transgenic hybrids between B. napus and B. rapa were found (Aono et al. 2011). Under the influence of climatic conditions, the properties of feral transgenic oilseed rape plants might have changed. Plants with greater height that have also become perennial were found (Kawata et al. 2009), whereas oilseed rape and all other Brassica species growing in Japan are usually annual.

\section{Australia}

In Western Australia, herbicide tolerant oilseed rape is cultivated only in certain areas and makes up less than ten percent of the overall oilseed rape acreage (McCauley et al. 2012). Nevertheless, more than $60 \%$ of the samples taken from feral oilseed rape populations tested positive for glyphosate tolerance (Conservation Council of Western Australia CCWA 2012).

\section{European Union}

Although transgenic oilseed rape was never admitted for cultivation in theEuropean Union, several field trials have taken place, the "transgen" website lists 383 in 11 countries. ${ }^{5}$ In Germany (North Rhine-Westphalia) feral genetically modified oilseed rape was found $700 \mathrm{~m}$ from a former trial field (Hofmann et al. 2007). Even ten years after field trials, transgenic oilseed rape was found in Sweden (D'Hertefeldt et al. 2008). In Austria, feral conventional oilseed rape single plants up to large populations as well as related wild hybridisation partners were regularly identified along transportation routes, border railway stations, railway stations, at switchyards, ports and oil mills (Pascher et al. 2017). Feral populations were also observed in France (Garnier et al. 2008; Pivard et al. 2008), the Netherlands (Tamis and De Jong 2010) and Great Britain (Crawley and Brown 2004; Squire et al. 2011).

\section{Switzerland}

Fifty out of 2400 oilseed rape individuals collected along railway tracks throughout Switzerland proved positive for the presence of the transgenic Roundup Ready characteristic enzyme that confers glyphosate tolerance (Schoenenberger and D'Andrea 2012). Another study confirmed these findings and identified hot spots of transgenic plants at locations were unloading takes place (Hecht et al. 2014). These hot spots were ports and railway stations bordering to France and Italy, despite Switzerland's import ban (Schulze et al. 2015, 2014).

\footnotetext{
${ }^{5}$ www.transgen.de.
} 
It can be considered as empirically confirmed that transgenes in oilseed rape are not limited to cultivation only, but can be found regularly as feral and as volunteer plants under a wide variety of geographic and ecological conditions.

\section{Modelling Approaches for Gene Drives}

There have been multiple attempts to model the gene flow of B. napus. Two of the most advanced approaches will be presented here. To model the population dynamics of a gene drive, possible modifications to existing models will be proposed. The two models explored are the GeneSys model established by Colbach et al. (2001a, b) and GeneTraMP by Middelhoff et al. (2011).

Another potentially relevant model was established by (Maxwell et al. 2015) which assumes a theoretical weed species and predicts the evolution and dynamics of herbicide resistance. On the basis of fungal spore dispersal, the model simulates pollen transfer between spatial entities assessing the interaction between herbicide application and plant genotype. Furthermore, Habekotté (1993, 1997a, b) established an empirical model BRASNAP-PH to predict key times of flowering and maturity of winter oilseed rape based on temperature and insolation. Some of her findings were included as input data in GeneSys and GeneTraMP.

\section{GeneSys}

The model was conceived to evaluate the effects of different cropping systems on gene flow in oilseed rape. It integrates the effects of crop succession and management at the level of a region. Simulation duration and crop succession and cultivation techniques are defined by the user. The model simulates the annual life cycle of cultivated and volunteer oilseed rape, starting with the seed bank at harvest and determining seedling emergence. Seedlings grow, flower and produce new seeds, some of which replenish the seed bank. At the end of each stage, the number of individuals per square meter is calculated. The seed bank is divided into four soil layers. Accordingly, seeds are distinguished by their respective layer and age, subdivided into young and old (older than one year) with related survival rates according to data by (Schlink 1994). The seeds' position in the soil layers may be changed by stubble breaking and the numbers of seeds and post-harvest seedlings may be reduced by pre-sowing tillage. Three tillage regimes are distinguished, stubble-breaking, ploughing and rigid-tine cultivation. Herbicide applications can be conducted after sowing in spring with mortality rates of 90 or $85 \%$, respectively. Adult survival depends on vernalisation and density dependent intra- and interspecific competition. Newly formed seeds are deposited in the upper soil layer. The maximum adult oilseed rape plant density was taken from Freudhofmaier (1991) and Vullioud (1992), flower and seed production values from (Leterme 1985). The competitiveness of crop plants to volunteer plants 
was deduced by division of the maximum plant densities of the subsequent crop. Oilseed rape's seed loss rate can be specified as a variable parameter. Seedling emergence rates, effects of the sowing date, number of flowers and flower duration were experimentally assessed, considering tillage and intercrop periods. To integrate herbicide resistant varieties, the user can define the genotype as dominant or recessive, homozygous or heterozygous. Furthermore, self-pollination rate as well as seed and pollen production rate must be defined in accordance with the particular variety. The model deterministically considers pollen and seed transfer between fields and random import of foreign seed and contamination with foreign pollen. However, Couturaud (1998) shows that GeneSys tends to underestimate pollen and seed dispersal.

The model works with an aggregated plant representation and does not integrate individual plants, neither in nor outside the cropping area. Furthermore, it does not take differentiated climate response of the plants into consideration. Different genotypes in the model do not exhibit different developmental characteristics such as the onset of flowering. The model GeneSys has, however, been successfully applied in the definition of management rules for the commercial release of GM-oilseed rape crops in Europe (Bock et al. 2002; Messean et al. 2006).

\section{GeneTraMP}

The GeneTraMP model (Generic Transgene Movement and Persistence) was developed to assess regional effects of a large scale cultivation of GM-oilseed crops. Input data include results of landscape and climate analysis (Schmidt and Schröder 2011), satellite image processed oilseed rape distribution (Breckling et al. 2011) and regional crop management schemes (Glemnitz et al. 2011). This allows to analyse spatio-temporal dynamics of gene flow with implemented human crop management activities. The model differentiates between feral and volunteer plants as well as aggregated crop plant cohorts. Different genotypes, regarding cygosity, dominance or recessiveness and ploidy can be distinguished and implemented to simulate transgene spread. The model considers three types of pollen transfer: local pollen mass flow, insect-borne pollen transfer and unspecific regional background pollen transfer across larger distances. Pollination is dependent on the spatio-temporal distribution of flowering plants, the number of open flowers and their respective state of fertility. For the individual plant development, the model distinguishes five stages: seed, seedling, start of flowering, end of flowering and maturity. Progression through these stages is in accordance with climatic and environmental parameters. Seeds are further specified by one of four soil layers and their age, divided into young and old (older than one year), following (Nathalie Colbach et al. 2001). Also in accordance with GeneSys, seed persistence and germination decisions are calculated in dependence on temperature and moisture regimes. The temperature-dependent oilseed rape germination parameters were derived from (Habekotte 1997a) with the additional need for one rainy day in the week before germination. Plant development, flowering 
progress, flower and seed numbers were derived from Habekotté (1993, 1997a, b) and Cramer (1990).

Human activities are included in the form of cultivation practices, crop rotation, intensity and distribution of feral plants as a result of seed loss and road verge clearing activities. The model uses the same three tillage regimes as GeneSys. Weed control is implemented either as cutting, selective or total herbicide application. Information concerning crop management schedules and procedures in Germany were derived from a field cultivation survey (Zander 2003). The occurrence of volunteers is estimated for different subsequent crops in probability and density, according to field observations (Menzel 2006) and in dependence of environmental conditions. During oilseed rape harvest procedures, a stochastic amount of seeds is transferred to neighbouring grid cells, specified as ruderal areas. Feral oilseed rape plants are distinct from cultivation crop plants in frequency, size, number of inflorescences, flowering progress, pod forming rate and seed number per pod.

\section{Model Suitability to Represent Gene Drive Population Dynamics}

Both models are compared in Table 5.3. From these observations, it is obvious that the more recent GeneTraMP model, which in part is even based on the GeneSys model does not only contain more ecological details, but would be also more suitable to model the spread of gene drive oilseed rape plants. Even though, the model would have to be adjusted and requires further refinements for this purpose.

In order to use the GeneTramp model for the assessment of gene drive population dynamics and their spatio-temporal spread, certain additions to the program would have to be made. For instance, the model is already capable to simulate genotypes of transgenic varieties and their spread as volunteers and feral populations. For gene drive, the inheritance of such an organism as well as its genotypic characteristics would have to be implemented. Furthermore, potential side effects of the gene drive, such as an eventually reduced fitness would have to be implemented. At the current state of research, however, parameters concerning these side effects would be based on assumptions or require new empirical data. It would have to be decided whether a gene drive-carrier produces a mass of pollen or seeds that deviate from the conventional plants and whether and how gene drive organisms deviate in their life cycle. Apart from such considerations an even more significant issue might be to finalise the inclusion of oilseed rape's hybridisation partners which was not yet done due to the lack of appropriate data. Furthermore, if these were included, the next issue would be the consideration of introgression events. However, the GeneTraMP model was already successfully applied to simulate the occurrence of plants with multiple herbicide resistances emerging from single-resistant GM-oilseed rape crops cultivated in adjacent fields as was previously shown to occur in Canada (Hall et al. 2000). The model could be used to simulate not only a gene drive or the spread of resistance 
Table 5.3 Comparison of the GeneSys and GeneTraMP models

\begin{tabular}{l|l|l}
\hline Aspect & GeneSys & GeneTraMP \\
\hline Regions & $\begin{array}{l}\text { Small } \\
\text { (Ile-de-France) }\end{array}$ & $\begin{array}{l}\text { Large (Northern Germany), } \\
\text { 4 different climate zones }\end{array}$ \\
\hline Pollen transfer & $\begin{array}{l}\text { Deterministic field to field, } \\
\text { Random pollen import }\end{array}$ & $\begin{array}{l}\text { Local pollen mass flow } \\
\text { Insect borne transfer } \\
\text { Regional long distance transfer }\end{array}$ \\
\hline Seed transfer & Empirical values & - \\
\hline Seed loss & User defined rate & $\begin{array}{l}\text { Randomly determined from } \\
\text { literature ranges }\end{array}$ \\
\hline Plant development & $\begin{array}{l}\text { Uniform from empirical data } \\
4 \text { seed stages, 2 seedling stages, } \\
2-3 \text { adult stages, flowers, 2 new } \\
\text { seed stages }\end{array}$ & $\begin{array}{l}\text { Temperature and precipitation } \\
\text { dependent } \\
\text { seed, seedling, start of flowering, } \\
\text { end of flowering, maturity }\end{array}$ \\
\hline Crop rotation & User defined & $\begin{array}{l}10 \text { most widely applied generic, } \\
\text { area specific rotations }\end{array}$ \\
\hline Cultivation densities & - & 3 \\
\hline Genotypes & $\begin{array}{l}\text { Dominant-recessive, } \\
\text { Cygosity }\end{array}$ & $\begin{array}{l}\text { Dominant-recessive, } \\
\text { Cygosity, Ploidy }\end{array}$ \\
\hline Herbicides & Up to two (unspecified) & One (unspecified) \\
\hline Crop management & $\begin{array}{l}\text { User defined, Tillage, cutting, } \\
\text { chisel, herbicide treatment }\end{array}$ & $\begin{array}{l}\text { Included Ploughing, rigid tine, } \\
\text { both }\end{array}$ \\
\hline Populations & Crop, volunteer & Crop, volunteer, feral \\
\hline Soil layers & 4 & 4, analogous to GeneSys \\
\hline Hybridisation partners & - & Not yet fully included \\
\hline
\end{tabular}

genes but also the combination of both and the ultimate formation of resistancecarrying gene drive-carriers. Given the necessary input, it would even be possible to model the application of gene drives to target and remove herbicide resistances in volunteer and feral populations.

\section{Suitability and Prerequisites of Oilseed Rape for Gene Drives?}

Ideally, the target organisms for a gene drive would exist in geographically isolated populations. Wherein, the migration of individuals from one population to another does (at best) not occur. Target organisms must reproduce sexually with relatively short generation times. Non-overlapping generations would thereby allow an easier assessment of the gene drive's spread in the population. Furthermore, the target organism should be diploid and its genome should already be well studied, in the context of gene expression patterns over the course of its development, while sequence 
variations within the targeted genes should be rare. The mutation rate of the target organism should also be low. Moreover, there should be no interspecific mating events, barring the creation of gene drive-carrying hybrids. Lastly, the application of a gene drive is a risky intervention into, not only the genome of a target species but also its ecosystem, which may harbour unforeseen consequences. Therefore, experts recommend to only consider (at least CRISPR/Cas-based gene drives) for applications that, if successful, have an extraordinarily high level of benefit for large majorities. Such aims include the population control of vector species for diseases, such as for malaria. Multiple approaches to tackle the disease have been suggested (Burt et al. 2018). The application of gene drives for conservational goals such as invasive species control on the other hand, is controversial and considered too risky-or for some experts the risks would outweigh the intended benefits (Esvelt and Gemmell 2017).

According to several already mentioned aspects, it is foreseeable that oilseed rape does not fit well the criteria for an ideal gene drive target organism. This is further illustrated in Table 5.4. Oilseed rape is an allotetraploid plant complicating the engineering and propagation of a potent gene drive system, albeit the genome is well studied also due to the many available transgenic variants. The genetic variability of modern oilseed rape varieties are low due to the two bottlenecks in selective breeding for low erucic acid and low glucosinolate content (Bus et al. 2011). However, in a study of the allelic diversity of 72 varieties of oilseed rape from five different countries, Chen et al. (2007) found a total of 59 private alleles of which 21 are shared with other Brassica species. On the one hand, the spread of gene drive pollen would be partially reduced due to the fact that oilseed rape is self-compatible. On the other hand, spatial confinement of a gene drive would be nearly impossible as oilseed rape is cultivated around the world and many feral populations exist, mainly due to seed losses along transportation routes. Additionally, pollen is dispersed over long distances. The occurrence of feral populations also makes the confinement of

Table 5.4 Requirements for an ideal gene drive target organism

\begin{tabular}{l|l}
\hline Ideal target organism & Oilseed rape \\
\hline Diploid & Allotetraploid \\
\hline Geographically isolated & Cultivated around the world \\
\hline Low genetic variability & Low due to selective breeding \\
\hline Low migration rate & Long range pollen dispersal, transportation losses \\
\hline Low mutation rate and genetic diversity & $?$ \\
\hline No interspecific gene flow & Interspecific gene flow with introgression \\
\hline Non-overlapping generations & $\begin{array}{l}\text { Overlapping generations due to perennial Feral } \\
\text { plants and secondary dormancy }\end{array}$ \\
\hline Sexual reproduction & High self-compatibility \\
\hline Short generation times & Annual or even perennial \\
\hline Well studied genome & Many transgenic variants \\
\hline
\end{tabular}


a gene drive to the target population and even target species difficult, as the plant possesses many hybridisation partners. Temporal confinement is a major problem due to the long generation times and even overlapping generations in the case of perennial stocks. This last point is even further aggravated due to the secondary dormancy, which allows certain seeds to remain dormant in seed banks for over a decade (Pekrun 1994).

An even greater problem is that oilseed rape is an agricultural product. It is therefore likely that gene drive pollen could fertilize conventionally grown oilseed rape. On the one hand, this would reduce the spread of the gene drive as these plants are harvested annually. But on the other hand it likely will give rise to gene drive volunteer plants which may be detrimental to organic farmers and socially not well-received even in conventional cropping.

\section{Purposes for Oilseed Rape Gene Drives?}

In general, gene drives can be subdivided by their intended goal to either suppress or replace/modify wild populations, to disperse certain alleles in a population, or to limit genetic exchange with other populations. In most techniques, this is decided by the cargo genes associated with the drive mechanism. Suppression might, for instance, be achieved by driving stimulus specific vulnerabilities (to either low or high temperatures or certain chemicals) into the population. A modification to suppress volunteering without suppressing the population might entail the deletion or repression of the genes responsible for secondary dormancy. Suppression could also be achieved by infertility. Especially female infertility may be a desirable trait to prevent the hybridisation with other plant species, as hybridisation with oilseed rape is mostly successful with B. napus as the female parent (Scheffler and Dale 1994). Organisms with infertile female sex organs would also not produce seeds but still produce and disperse pollen and could thereby propagate the trait.

As already predicted in 2004 and even before, the cultivation of transgenic oilseed rape has led to transgene escape into feral populations (Breckling and Menzel 2004). As the examples of five different countries and the EU show, transgenic contamination and concomitant dispersal of herbicide resistance genes is a serious issue which supports an invasion of feral transgenic oilseed rape into many ecosystems. This eventually leads to the potential gene flow and introgression of transgenic herbicide resistances to other hybridisation partners of oilseed rape. This may negatively affect the integrity of genetic resources in wild relatives (Londo et al. 2010).

Furthermore, we are currently experiencing an anthropomorphic downward spiral in agriculture, called the pesticide treadmill. Due to the broad application of herbicides weeds with single or multiple resistances, so called superweeds emerge. Therefore, the development of new generations of pesticides is required for maintaining of pesticide protected industrial agriculture. These will however, eventually be followed by yet another generation of superweeds and the vicious cycle continues [For a scope of the pesticide treadmills governance issues see Bain et al. (2017)]. 
Gene drive applications might potentially stop or at least slow down this vicious cycle, but may also cause new problems.

This section is therefore dedicated to the exploration of conceivable gene drive applications with the goal to get rid of transgenic feral and volunteer populations of oilseed rape.

\section{Gene Drives to Delete/Block Herbicide Resistances}

We consider the possibility to eliminate or reduce the occurrence of herbicide resistance from undesirable escape of transgenes to the wild and their persistence in feral populations. To reduce the occurrence of herbicide-resistant feral populations, an obvious target locus for a gene drive would be the resistance genes themselves. Despite heavy outcrossing of the feral populations, the resistance genes confer a fitness gain and are therefore likely to become conserved.

\section{CRISPR/Cas-Based Approaches}

It might seem at least feasible to use a CRISPR/Cas-based gene drive to target all different herbicide resistance-loci in order to delete or disrupt them by homing cargo genes into them. The gene drive would confer a fitness penalty, which might cause the gene drive carrying oilseed rape to vanish after a number of generations. Multiple releases over several years might be necessary. Furthermore, this fitness penalty would favour the selection for gene drive resistant alleles. However, considering the large number of herbicide resistant variants this would require many gRNAs, most likely resulting in a higher genetic load which may confer an even higher fitness penalty.

The formation of resistance alleles, due to non-homologous end joining instead of homology-directed repair, would on one hand impede the copying of the gene drive cassette, but may on the other hand cause a null-mutation in the present resistance allele. This would constitute a positive side effect of imperfect repair not present in other gene drive approaches currently discussed.

Probably, the most problematic issue of this approach is the potential crossfertilisation of (feral) gene drive oilseed rape with cultivated transgenic varieties. The seeds of these crosses would also carry the gene drive and might remain in the seed bank for decades being able to restart the gene drive. Furthermore, this gene drive oilseed rape may occur as volunteer in subsequent crop rotations. Another problematic aspect would be the risk of an outcrossing to related species. 


\section{Resistance Blocking}

An alternative pathway could include either miRNA cargo genes that target the resistance genes' mRNAs or cargo genes for proteins that either repress the gene expression of the resistances or inactivate the gene product post-translationally. While a CRISPR/Cas-based approach would act only once in the germline, this alternative approach would require a constitutive gene expression throughout the life cycle of the plant to block resistance. These cargo genes would therefore confer a high fitness penalty and thus be subject to mutational changes. Since a single base pair deletion could lead to reading frame shifts in the genes of proteins, this may be detrimental to the gene drive and may in the end result in carrier-organisms retaining partial resistance. This effect would probably be less pronounced when using miRNAs to block resistance instead of proteins. But then, multiple RNAs should be included within the gene drive cassette to silence a single resistance gene. But despite a successful gene drive application, the population would then still retain the resistance genes.

\section{Overwriting Various Herbicide Resistances with a Single Resistance}

It might be feasible to equip the gene drive with resistance against a newly designed herbicide including the implication to overwrite or disrupt existing resistances. If such a gene drive would be used in cultivation and successively spread to feral populations, it might be an approach to eliminate herbicide resistances from feral populations. This, however, would be a long-term and large scale intervention.

It is obvious that such an approach is based on some major assumptions which seem difficult to achieve. Another problematic issue would be the almost impossible monitoring of such a gene drive's spread in feral populations. Moreover, it would be necessary to sow gene drive oilseed rape into identified feral populations which is especially time-consuming and makes the applications of a gene drive hardly useful, as the feral population could simply be destroyed instead.

\section{Self-Limiting CRISPR/Cas-Based Approaches}

A more confineable CRISPR-based technique would simply cut out the resistance alleles without propagating the CRISPR/Cas-system itself. This self-limiting approach would, therefore, not constitute a gene drive. Thus, multiple mass-releases would be necessary, although their seeds may remain in the seed bank for multiple generations as well. However, these individuals carrying non-functional resistance 
genes would be less fit than their resistant conspecifics and probably even less fit than conventional non-GMO oilseed rape stocks.

Finally, there is the possibility of self-limiting CRISPR/Cas-based gene drives, e.g. the daisy-chain drive. A daisy drive system consists of multiple gene drives in which each element drives the next element in the chain. The bottom element is lost from the population first, then the next element ceases to drive and gets lost from the population and so on. This process continues upwards in the chain until, eventually, the population returns to its wild-type state with regard to the expression of genes expressing intended artificial functionalities (Noble et al. 2016). This approach would limit the spread of a gene drive in time and space which on one hand would increase controllability, but on the other hand would be less desired in the case of the widely spread feral populations.

\section{Gene Drive Seeds as a Breeding Tool on Agricultural Fields}

To take this thought one step further, though ecologically not really desirable, it might be feasible to sow gene drive carrying oilseed rape on agricultural fields. Although it seems unlikely to have farmers being willing to sow gene drive-carrying oilseed rape within the EU, there may be functionalities of such an approach. The characteristics of the gene drive could be that of the resistance-overwriting approach which would overwrite existing herbicide resistances (and gene drives) with a single resistance. This might also help in accelerating breeding procedures towards the reproduction of basic seed. After a number of generations, taking into account the spread of the gene drive to feral populations and the persistence in the seed banks, a switch of overwriting drive carrying oilseed rape and herbicide might be performed. The advantage would be the seed losses during transportation, which would guarantee a wide spread of the gene drive and enable it to reach more distant feral populations.

While currently, new herbicides have to be developed again and again to overcome the emerging formation and outcrossing of resistances, this approach would allow to alternate between a limited set of herbicides, if extended towards additional weed species. Since the massive use of a limited number of active herbicide ingredients led to the selection of major problematic weeds worldwide and in particular in those agricultural systems using herbicides extensively (Heap 2014). The alternative in organic agriculture would be adequate crop rotations and the sustaining of a rich biodiversity in the surrounding landscape to limit pest outbreaks.

\section{Female Infertility Drive}

This paragraph serves to further explore the thought experiments of a gene drive conferring female infertility. As mentioned above, this could be achieved by repressing or even deleting the genes responsible for the development and functioning of the 
plants' stigma or gamete production. To be able to mass-produce these organisms in the laboratory, it needs to be equipped with a repressor mechanism, which would allow normal development in the presence of a certain chemical, as is the case in the Release of Insects carrying a Dominant Lethal (RIDL)-system (Thomas et al. 2000). Assuming again, a drive propagation by the transformative action of a CRISPR/Casbased gene drive, a high conversion rate could be expected. The drive would only propagate via pollen. It would not remain in the seed bank, because it is unable to produce seeds. In order to pursue the set goal of the suppression of transgenic feral populations, the drive could again home in on various resistance gene sequences. Thus, only the offspring of transgenic parents would be converted to homozygous carriers, while non-GMO parents would give rise to heterozygous offspring. The latter would be the case, if the gene drive pollen was to fertilize cultivated plants. Assuming for the female infertility to only homozygously be effective, the crosspollination of cultivated gene drive crops would not pose a threat to conventional agriculture. Instead, it would reduce the occurrence of volunteer plants in subsequent crop rotations. Furthermore, this would cause the drive to be almost self-limiting, as it would stop its propagation, if no transgenic plants are fertilized for several generations. However, in this scenario, multiple releases over several decades would again be necessary.

\section{Other Gene Drive Techniques Besides CRISPR/Cas}

Up to this point, the considered gene drive applications revolved around drives propagated by the CRISPR/Cas system. To complete the available drive systems, we discuss them below.

\section{Medea (Maternal Effect Dominant Embryonic Arrest)}

This technique uses a toxin-antidote combination that causes it to be inherited with a super-Mendelian frequency. The maternally expressed toxin is deposited in the embryo and only if that embryo inherits the gene drive, it will be able to counteract the toxin with the appropriate antidote. This functionality was discovered occurring naturally in Tribolium flour beetles. It was first synthetically engineered in Drosophila (Akbari et al. 2014). In principle, Medea constitutes a modification drive designed to be able to replace wild populations.

\section{Underdominance}

The phenomenon of Underdominance causes heterozygous carriers to receive a higher fitness penalty than homozygous carriers. This can be achieved by toxinantidote combinations, either similar to the Medea technique (Akbari et al. 2013), or containing an miRNA toxin, targeting a vital gene, and a recoded but haploinsufficient version of the gene (Reeves and Reed 2015). Underdominance constitutes a modification drive as well, but different from Medea depends on a higher threshold within a population in order to drive the desired traits to fixation. 


\section{Killer-Rescue}

Independently inherited toxin (killer) and antidote (rescue) alleles will transiently increase the rescue alleles (fused to cargo genes) prevalence within a population. The lethal killer alleles will be quickly selected from the population and as soon as this happens, the rescue alleles will no longer confer a fitness gain and therefore, will be reduced in frequency in the population as well (Gould et al. 2008).

All three toxin-antidote techniques may potentially be applicable for gene drives in oilseed rape. Albeit up until now, none of these techniques has been developed for plant species. Whether their functionality in allotetraploid plants would be comparable to that in diploid animals is therefore unknown. The ideas presented above, could be incorporated into these drive mechanisms as well with the exception of the female infertility trait in combination with the Medea or the Medea-related Underdominance drive systems because these techniques rely on a maternally deposited toxin to select against offspring not carrying the drive construct(s).

\section{Meiotic drives}

These naturally occurring drive systems rely on the distortion of chromosome segregation during meiosis. The most widely discussed approach in this category is the $\mathrm{X}-$ Shredder technique, which in sexually reproducing animals distorts the sex ratio by targeting the $\mathrm{X}$-chromosome with nucleases. If the necessary genes are located on the Y-chromosome, this can result in a male bias of up to $95 \%$ (Galizi et al. 2014). Although the sex determination in plants is more complex than in animals and oilseed rape is monoecious, as each plant has both sexes united in perfect flowers, the Bassicaceae family belongs to the group of eurosids II, which were shown to possess sex chromosomes (Charlesworth 2002). Therefore, it might be feasible to engineer a drive system resembling the X-Shredder technique in oilseed rape. Wherein, carrier-organisms may produce a high percentage of androcious offspring. These would be able to propagate via pollen.

This drive, however, useful to suppress feral populations would again be problematic due to the fertilisation of cultivated crops. The consequence would be gene drive-carrying volunteers. Furthermore, by hybridisation events, this drive might invade other species, distorting their sex ratios as well. This would most likely prove detrimental for the flora with potential secondary effects to the fauna of a vast number of ecosystems. However unlikely, such an event seems probable considering the long lasting persistence of the drive due to volunteering, formation of feral populations and long-term persistence in the seed bank inherent to oilseed rape. Even events with an extremely low probability become significant, given enough time and a large sample size (Diaconis and Mosteller 1989). 


\section{Conclusion}

This case study presented oilseed rape in its agricultural significance, its ecological interconnections as well as its survival and propagation strategies. It pointed to the numerous potential hybridisation partners, lists some of the transgenic varieties and stressed the emerging problem of escaping transgenes into the environment. Existing computer programs applicable to model the gene flow of oilseed rape and the spread of those escaping transgenes were reviewed and compared, especially points of improvement in the light of the simulation of gene drive were emphasised. Finally, the suitability of oilseed rape as a target organism for gene drives was scrutinized and furthermore multiple ideas for the various, currently discussed gene drive approaches were exercised in thought experiments in various modes with different potential cargo genes.

In summary, the application of a gene drive to oilseed rape as target organism would be laborious to engineer, very difficult to confine, almost impossible to adequately monitor and would require multiple mass releases across large areas and long time spans. Such an endeavour would be very costly. The risk of losing control would increase over time, and considering the long time frame would almost be certain. In face of the (apparently mild or negligible) benefits, a successful gene drive would harbour the reduction of transgene escape into feral populations or, economically more interesting, potentially slowing down the pesticide treadmill. These circumstances make the application of an oilseed rape gene drive an unfavourable bargain. Therefore, such an application is not recommended. It was demonstrated that various risk dimensions are required to be considered. Among these are stability and dispersal issues, gene flow and complex spatial crop-volunteer-feral plant interactions, not to mention conservation and public acceptance issues. Although oilseed rape is not a good target organism for gene drive applications, it points out a panoply of relevant issues that may arise in part or in various combinations, when considering other possible plant target organisms for gene drive.

The major value of the considerations is not the expectation of a near-future application of SPAGE in oilseed rape. Instead, we intended this case study to emphasize the diverse issues which are crucial for an implication analysis in plants. Oilseed rape is an excellent example for such an exercise, since it allows to exemplify the dimensions of the physiological, ecological, environmental and agricultural context, which is relevant also for the risk assessment of other potential botanical candidates for genetic modification of the considered types. 


\section{References}

Adler, L. S., Wikler, K., Wyndham, F. S., Linder, C. R., \& Schmitt, J. (1993). Potential for persistence of genes escaped from canola: germination cues in crop, wild, and crop-wild hybrid Brassica rapa. Functional Ecology, 736-745.

Adolphi, K. (1995). Neophytische Kultur-und Anbaupflanzen als Kulturflüchtlinge des Rheinlandes. Galunder.

Akbari, O. S., Chen, C.-H., Marshall, J. M., Huang, H., Antoshechkin, I., \& Hay, B. A. (2014). Novel synthetic Medea selfish genetic elements drive population replacement in drosophila, and a theoretical exploration of Medea-dependent population suppression. ACS Synthetic Biology, 3, 015-928.

Akbari, O. S., Matzen, K. D., Marshall, J. M., Huang, H., Ward, C. M., \& Hay, B. A. (2013). A synthetic gene drive system for local, reversible modification and suppression of insect populations. Current Biology, 23, 671-677. https://doi.org/10.1016/j.cub.2013.02.059.

Ammann, K., \& Vogel, B. (1999). Langzeitmonitoring gentechnisch veränderter Organismen. Bestandsaufnahme, Fallbeispiele und Empfehlungen. Kantonales Laboratorium Basel-Stadt Kontrollstelle für Chemie und Biosicherheit (KCB) 70.

Aono, M., Wakiyama, S., Nagatsu, M., Kaneko, Y., Nishizawa, T., Nakajima, N., et al. (2011). Seeds of a possible natural hybrid between herbicide-resistant Brassica napus and Brassica rapa detected on a riverbank in Japan. GM Crops, 2, 201-210.

Aono, M., Wakiyama, S., Nagatsu, M., Nakajima, N., Tamaoki, M., Kubo, A., et al. (2006). Detection of feral transgenic oilseed rape with multiple-herbicide resistance in Japan. Environmental Biosafety Research, 5, 77-87.

Augustin, C., Becker, R., Gottwald, R., Hedtke, C., Hornermeier, B., Lentzsch, P., et al. (1998). Ökologische Auswirkungen der Einführung der Herbizidresistenz (HR)-Technik bei Raps und Mais. - Gutachten für das Ministerium für Umwelt, Naturschutz und Raumordnung (MUNR) des Landes Brandenburg. Eigenverlag.

Bain, C., Selfa, T., Dandachi, T., \& Velardi, S. (2017). 'Superweeds' or 'survivors'? Framing the problem of glyphosate resistant weeds and genetically engineered crops. Journal of Rural Studies, $51,211-221$.

Baranger, A., Chevre, A. M., Eber, F., \& Renard, M. (1995). Effect of oilseed rape genotype on the spontaneous hybridization rate with a weedy species: An assessment of transgene dispersal. Theoretical and Applied Genetics, 91, 956-963.

Bauer-Panskus, A., Hamberger, S., Then, C. (2013). Transgene Escape-Atlas der unkontrollierten Verbreitung gentechnisch veränderter Pflanzen.

Becker, T. H. (1951). Siebenjährige blütenbiologische Studien an den Cruziferen Brassica napus L., Brassica rapa L., Brassica oleracea L., Raphanus L. und Sinapis L.. Teil I. Zeitschrift für Pflanzenzüchtung, 29, 222-240.

Beckie, H. J., \& Warwick, S. I. (2010). Persistence of an oilseed rape transgene in the environment. Crop Protection, 29, 509-512.

Bijral, J. S., \& Sharma, T. R. (1996). Intergeneric hybridization between Brassica napus and Diplotaxis muralis. Cruciferae Newslett. Eucarpia, 18, 10-11.

Bing, D. J., Downey, R. K., \& Rakow, G. F. W. (1991). Potential of gene transfer among oilseed Brassica and their weedy relatives. GCIRC Rapeseed Congr., 1991, 1022-1027.

Bock, A.-K., Lheureux, K., Libeau-Dulos, M., Nilsagard, H., \& Rodriguez-Cerezo, E. (Eds.), (2002). Scenarios for co-existence of genetically modified, conventional and organic crops in European agriculture. IPTS-JRC study.

Braatz, J., Harloff, H.-J., Mascher, M., Stein, N., Himmelbach, A., \& Jung, C. (2017). CRISPRCas9 targeted mutagenesis leads to simultaneous modification of different homoeologous gene copies in polyploid oilseed rape (Brassica napus). Plant Physiology, 174, 935. https://doi.org/10. 1104/pp.17.00426.

Breckling, B., Borgmann, P., Neuffer, B., Hurka, H., Tappeser, B., Brauner, R., Menzel, G., Born, A., Schmidt, G., Schröder, W., Laue, H., Middelhoff, U., Baumann, R., Keßler, M., Reiche, E.-W., 
Rinker, A., Tillmann, J., Windhorst, W., Glemnitz, M., Wurbs, A., Funke, B., \& Brozio, S. (2004). GenEERA - Forschungsverbund Generische Erfassung und Extrapolation der Raps-Ausbreitung (Abschlussbericht). Universität Kiel.

Breckling, B., Laue, H., \& Pehlke, H. (2011). Remote sensing as a data source to analyse regional implications of genetically modified plants in agriculture-oilseed rape (Brassica napus) in Northern Germany. Ecological Indicators, 11, 942-950.

Breckling, B., \& Menzel, G. (2004). Self-organised pattern in oilseed rape distribution-An issue to be considered in risk analysis. In B. Breckling \& R. Verhoeven (Eds.), Risk hazard damage, specification of criteria to assess environmental impact of genetically modified organisms ( $\mathrm{pp}$. $73-$ 88). Bundesamt für Naturschutz, Bonn.

Brown, J., \& Brown, A. P. (1996). Gene transfer between canola (Brassica napus L. and B. campestris L.) and related weed species. Annals of Applied Biology, 129, 513-522.

Burt, A., Coulibaly, M., Crisanti, A., Diabate, A., \& Kayondo, J. K. (2018). Gene drive to reduce malaria transmission in Sub-Saharan Africa. Journal of Responsible Innovation, 5, S66-S80. https://doi.org/10.1080/23299460.2017.1419410.

Bus, A., Körber, N., Snowdon, R. J., \& Stich, B. (2011). Patterns of molecular variation in a specieswide germplasm set of Brassica napus. Theoretical and Applied Genetics, 123, 1413-1423. https://doi.org/10.1007/s00122-011-1676-7.

Chalhoub, B., Denoeud, F., Liu, S., Parkin, I. A., Tang, H., Wang, X., et al. (2014). Early allopolyploid evolution in the post-Neolithic Brassica napus oilseed genome. Science, 345, 950-953.

Charlesworth, D. (2002). Plant sex determination and sex chromosomes. Heredity, 88.

Chen, B. Y., Heneen, W. K., \& Jönsson, R. (1988). Resynthesis of Brassies napus L. through interspecific hybridization between B. alboglabra Bailey and B. campestris L. with special emphasis on seed colour. Plant Breeding, 101, 52-59.

Chen, S., Nelson, M. N., Ghamkhar, T., Fu, T., \& Cowling, W. A. (2007). Divergent patterns of allelic diversity from similar origins: the case of oilseed rape (Brassica napus $L$.) in China and Australia. Genome, 51, 1-10. https://doi.org/10.1139/G07-095.

Chèvre, A. M., Ammitzbollz, H., Breckling, B., Dietz-Pfeilstetter, A., Eber, F., Meier, M. S., Den NiJs, H. C. M., Pascher, K., Seguin-Swartz, G., Sweet, J. B., Stewart, C. N. J., \& Warwick, S. I. (2004). A review on interspecific gene flow from oilseed rape to wild relatives. In Introgression from genetically modified plants into wild relatives. CABI Publishing, Cambridge.

Chèvre, A.-M., Eber, F., Baranger, A., \& Renard, M. (1997). Gene flow from transgenic crops. Nature, 389, 924.

Colbach, N., Clermont-Dauphin, C., \& Jean-Marc, M. (2001). GENESYS: A model of the influence of cropping system on gene escape from herbicide tolerant rapeseed crops to rape volunteers-I. Temporal evolution of a population of rapeseed volunteers in a field.

Colbach, N., Clermont-Dauphin, C., \& Meynard, J. M. (2001). GeneSys: A model of the influence of cropping system on gene escape from herbicide tolerant rapeseed crops to rape volunteers: II. Genetic exchanges among volunteer and cropped populations in a small region. Agriculture, Ecosystems \& Environment, 83, 255-270. https://doi.org/10.1016/S0167-8809(00)00175-4.

Conservation Council of Western Australia CCWA. (2012). A survey of roadside fugitive GM (Roundup Ready) canola plants at Williams. CCWA: Western Australia.

Couturaud, M. C. (1998). Effet des systèmes de culture sur les risques de dissémination du transgène de colza dans l'environnement: évaluation et utilisation du modèle GENESYS. INA PG, Paris: Mémoire de DAA.

Cramer, N. (1990). Raps: Züchtung, Anbau und Vermarktung von Körnerraps. Stuttgart, Ulmer. S 146.

Crawley, M. J., \& Brown, S. L. (2004). Spatially structured population dynamics in feral oilseed rape. Proceedings of the Royal Society of London B: Biological Sciences, 271, 1909-1916.

Crawley, M. J., Hails, R. S., Rees, M., Kohn, D., \& Buxton, J. (1993). Ecology of transgenic oilseed rape in natural habitats. Nature, $363,620-623$. 
Darmency, H., Lefol, E., \& Fleury, A. (1998). Spontaneous hybridizations between oilseed rape and wild radish. Molecular Ecology, 7, 1467-1473.

Devaux, C., Lavigne, C., Falentin-Guyomarc'h, H., Vautrin, S., Lecomte, J., \& Klein, E. K. (2005). High diversity of oilseed rape pollen clouds over an agro-ecosystem indicates long-distance dispersal. Molecular Ecology, 14, 2269-2280.

Devos, Y., De Schrijver, A., \& Reheul, D. (2009). Quantifying the introgressive hybridisation propensity between transgenic oilseed rape and its wild/weedy relatives. Environmental Monitoring and Assessment, 149, 303-322.

D’Hertefeldt, T., Jørgensen, R. B., \& Pettersson, L. B. (2008). Long-term persistence of GM oilseed rape in the seedbank. Biology Letters, 4, 314-317.

Diaconis, P., \& Mosteller, F. (1989). Methods for studying coincidences. Journal of the American Statistical Association, 84, 853-861.

Eber, F., Chèvre, A. M., Baranger, A., Vallée, P., Tanguy, X., \& Renard, M. (1994). Spontaneous hybridization between a male-sterile oilseed rape and two weeds. Theoretical and Applied Genetics, 88, 362-368.

Eckert, J. E. (1933). The flight range of the honeybee. Journal of Agricultural Research.

Eschmann-Grupe, G., Hurka, H., \& Neuffer, B. (2003). Species relationships within Diplotaxis (Brassicaceae) and the phylogenetic origin of D. muralis. Plant Systematics and Evolution, 243, $13-29$.

Esvelt, K. M., \& Gemmell, N. J. (2017). Conservation demands safe gene drive. PLOS Biology, 15, e2003850.

Feil, B., \& Schmid, J. E. (2001). Pollenflug bei Mais, Weizen und Roggen. Ein Beitrag zur Frage der beim Anbau von transgenen Kulturpflanzen erforderlichen Sicherheitsabstände. Institut f. Pflanzenbauwissenschaften, ETH Zürich.

Fischbeck, G. (1998). Sicherheitsforschung zu Freisetzungsversuchen in Roggenstein. Einführung und Ergebnisse zur Pollen- und Samenverbreitung transgener Erbeigenschaften. Verband Deutscher Biologen: Gentechnik, Ökologie und Ernährung, München 5-8.

Fischbeck, G., Heyland, K.-U., \& Knauer, N. (1982). Spezieller Pflanzenbau (2nd ed.). Stuttgart: Eugen Ulmer.

Förster, K., Schuster, C., Belter, A., \& Diepenbrock, W. (1998). Agrarökologische Auswirkungen des Anbaus von transgenem herbizidtoleranten Raps (Brassica napus L.). Bundesgesundheitsblatt, 41, 547.

Franzaring, J., Holz, I., Fangmeier, A., \& Zipperle, J. (2008). Monitoring the absence of glyphosate and glufosinate resistance traits in feral oilseed rape and wild crucifer populations. In Breckling, B., Reuter, H., \& Verhoeven, R. (Eds.), Implications of GM crop cultivation at large spatial scales (Vol. 14, pp. 90-92). Theorie in der Ökologie.

Freudhofmaier, O. (1991). Standraum und Ertragsstruktur von Raps. Raps, 9, 148-152.

Friesen, L. F., Nelson, A. G., \& Van Acker, R. C. (2003). Evidence of contamination of pedigreed canola (Brassica napus) seedlots in western Canada with genetically engineered herbicide resistance traits. Agronomy Journal, 95, 1342-1347.

Galizi, R., Doyle, L.A., Menichelli, M., Bernardini, F., Deredec, A., Burt, A., Windbichler, N., \& Crisanti, A. (2014). A synthetic sex ratio distortion system for the control of the human Malaria mosquito. Nature Communications, 5, 3977. https://doi.org/1038/ncomms4977

Garnier, A., Pivard, S., \& Lecomte, J. (2008). Measuring and modelling anthropogenic secondary seed dispersal along roadverges for feral oilseed rape. Basic and Applied Ecology, 9, 533-541.

Gerdemann-Knörck, M., \& Tegeder, M. (1997). Kompendium der für Freisetzungen relevanten Pflanzen; hier: Brassicaceae, Beta vulgaris, Linum usitatissimum. Texte, 38/97, Umweltbundesamt Berlin 221pp.

Gland, A. (1982). Gehalt und Muster der Glucosinolate in Samen von resynthetisierten Rapsformen. Z. Pflanzenzüchtung, 87, 613-617.

Glemnitz, M., Wurbs, A., \& Roth, R. (2011). Derivation of regional crop sequences as an indicator for potential GMO dispersal on large spatial scales. Ecological Indicators, 11, 964-973.

Gliddon, C. J. (1999). Gene flow and risk assessment. 
Gould, F., Huang, Y., Legros, M., \& Lloyd, A. L. (2008). A Killer-Rescue system for self-limiting gene drive of anti-pathogen constructs. Proceedings of the Royal Society B: Biological Sciences, 275, 2823-2829. https://doi.org/10.1098/rspb.2008.0846.

Gressel, J. (1999). Tandem constructs: Preventing the rise of superweeds. Trends in Biotechnology, 17, 379-388.

Habekotté, B. (1997a). Evaluation of seed yield determining factors of winter oilseed rape (Brassica napus L.) by means of crop growth modelling. Field Crops Research, 54, 137-151.

Habekotté, B. (1997b). A model of the phenological development of winter oilseed rape (Brassica napus L.). Field Crops Research, 54, 127-136.

Habekotté, B. (1993). Quantitative analysis of pod formation, seed set and seed filling in winter oilseed rape (Brassica napus L.) under field conditions. Field Crops Research, 35, 21-33.

Halfhill, M. D., Millwood, R. J., Raymer, P. L., \& Stewart, C. N., Jr. (2002). Bt-transgenic oilseed rape hybridization with its weedy relative, Brassica rapa. Environmental Biosafety Research, 1, $19-28$.

Hall, L., Topinka, K., Huffman, J., Davis, L., \& Good, A. (2000). Pollen flow between herbicideresistant Brassica napus is the cause of multiple-resistant B. napus volunteers. Weed Science, 48, 688-694.

Hansen, L. B., Siegismund, H. R., \& Jørgensen, R. B. (2001). Introgression between oilseed rape (Brassica napus L.) and its weedy relative B. rapa L. in a natural population. Genetic Resources and Crop Evolution, 48, 621-627.

Harberd, D. J., \& McArthur, E. D. (1980). Meiotic analysis of some species and genus hybrids in the Brassiceae. Meiotic analysis of some species and genus hybrids in the Brassiceae.

Heap, I. (2014). Herbicide resistant weeds. In D. Pimentel, R. Peshin (Eds.), Integrated pest management (pp. 281-301). Springer Netherlands, Dordrecht. https://doi.org/10.1007/978-94-0077796-5_12

Hecht, M., Oehen, B., Schulze, J., Brodmann, P., \& Bagutti, C. (2014). Detection of feral GT73 transgenic oilseed rape (Brassica napus) along railway lines on entry routes to oilseed factories in Switzerland. Environmental Science and Pollution Research, 21, 1455-1465.

Hofmann, N., Neubert-Kester, G., Gellermann, M., \& Thienel, T. (2007). Untersuchungen zur Verbreitung und Anreicherung von Transgensequenzen in der Umwelt über Auskreuzung und Bodeneintrag am Beispiel von HR-Raps. Bundesamt für Naturschutz.

Hühn, M., \& Rakow, G. (1979). Einige experimentelle Ergebnisse zur Fremdbefruchtungsrate bei Winterraps (Brassica napus oleifera) in Abhangigkeit von Sorte und Abstand. Zeitschrift fur Pflanzenzuchtung. $=$ Journal of plant breeding.

Hurka, H., Bleeker, W., \& Neuffer, B. (2003). Evolutionary processes associated with biological invasions in the Brassicaceae. Biological Invasions, 5, 281-292.

Ingram, J. (2000). The separation distances required to ensure cross-pollination is below specified limits in non-seed crops of sugar beet, maize and oilseed rape. Plant Varieties \& Seeds, 13, 181-199.

Klinger, T., \& Ellstrand, N. C. (1994). Engineered genes in wild populations: Fitness of weed-crop hybrids of Raphanus Sativus. Ecological Applications, 4, 117-120.

James, C. (2015). Global status of commercialized biotech/GM crops: 2014. ISAAA brief 49.

Janchen, E. (1972). Flora von Wien (p. 353). Verein für Landeskunde von Niederösterreich und Wien: Niederösterreich und Nordburgenland.

Jørgensen, R. B. (1999). Gene flow from oilseed rape (Brassica napus) to related species.

Jørgensen, R. B., \& Andersen, B. (1994). Spontaneous hybridization between oilseed rape (Brassica napus) and weedy B. campestris (Brassicaceae): A risk of growing genetically modified oilseed rape. American Journal of Botany, 1620-1626.

Jørgensen, R. B., Andersen, B., Landbo, L., \& Mikkelsen, T. R. (1996.) Spontaneous hybridization between oilseed rape (Brassica napus) and weedy relatives. In Acta Horticulturae. International Society for Horticultural Science (ISHS) (pp. 193-200), Leuven, Belgium. https://doi.org/10. 17660/ActaHortic.1996.407.23 
Jørgensen, R. B., Hauser, T., Mikkelsen, T. R., \& Østergård, H. (1996). Transfer of engineered genes from crop to wild plants. Trends in Plant Science, 1, 356-358.

Karpechenko, G. D. (1924). Hybrids of oRaphanus sativus L. x ơBrassica oleracea L. Journal of Genetics, 14, 375-396.

Kawata, M., Murakami, K., \& Ishikawa, T. (2009). Dispersal and persistence of genetically modified oilseed rape around Japanese harbors. Environmental Science and Pollution Research, 16, 120 126.

Kerlan, M. C., Chèvre, A. M., \& Eber, F. (1993). Interspecific hybrids between a transgenic rapeseed (Brassica napus) and related species: Cytogenetical characterization and detection of the transgene. Genome, 36, 1099-1106.

Kerlan, M. C., Chèvre, A. M., Eber, F., Baranger, A., \& Renard, M. (1992). Risk assessment of outcrossing of transgenic rapessed to related species. Euphytica, 62, 145-153.

Kimber, D. S., \& McGregor, D. I. (1995). Brassica oilseeds: Production and utilization. Cab international.

Knispel, A. L., \& McLachlan, S. M. (2010). Landscape-scale distribution and persistence of genetically modified oilseed rape (Brassica napus) in Manitoba, Canada. Environmental Science and Pollution Research, 17, 13-25.

Knispel, A. L., McLachlan, S. M., Van Acker, R. C., \& Friesen, L. F. (2008). Gene flow and multiple herbicide resistance in escaped canola populations. Weed Science, 56, 72-80.

Körber-Grohne, U. (1995). Nutzpflanzen in Deutschland von der Vorgeschichte bis heute. Stuttgart: Theiss Verlag.

Kumar, A., Premi, O. P., \& Thomas, L. (2007). Rapeseed-Mustard cultivation in India-An overview. National Research Centre on Rapeseed, Mustard, Bharatpur 321303 (Rajasthan).

Lamb, R. J. (1989). Entomology of oilseed Brassica crops. Annual Review of Entomology, 34, 211-229.

Landbo, L., Andersen, B., \& Jørgensen, R. B. (1996). Natural hybridisation between oilseed rape and a wild relative: Hybrids among seeds from weedy B. campestris. Hereditas, 125, 89-91.

Langhof, M., \& Rühl, G. (2017). Coexistence in oilseed rape: Effect of donor variety type and discarding field edges. Journal of Agricultural Science, 9, 33.

Lavigne, C., Klein, E. K., Vallée, P., Pierre, J., Godelle, B., \& Renard, M. (1998). A pollendispersal experiment with transgenic oilseed rape. Estimation of the average pollen dispersal of an individual plant within a field. Theoretical and Applied Genetics, 96, 886-896.

Leterme, P. (1985). Modélisation de la croissance et de la production des siliques chez le colza d'hiver application à l'interprétation de résultats de rendements. Thèse de Docteur-Ingénieur de l'Institut National Agronomique Paris-Grignon.

Londo, J. P., Bautista, N. S., Sagers, C. L., Lee, E. H., \& Watrud, L. S. (2010). Glyphosate drift promotes changes in fitness and transgene gene flow in canola (brassica napus) and hybrids. Annals Of Botany, 106, 957-965.

Lutman, P. J. W. (1993). The occurrence and persistence of volunteer oilseed rape (Brassica napus). Aspects of Applied Biology, 35, 29-36.

Männer, K. (2000). Haltbarkeit von pflanzlichen Verbreitungseinheiten nach Magen-Darm-Passage. UBA-Texte 19/00, Berlin.

Maxwell, P. S., Pitt, K. A., Olds, A. D., Rissik, D., \& Connolly, R. M. (2015). Identifying habitats at risk: Simple models can reveal complex ecosystem dynamics. Ecological Applications, 25, 573-587. https://doi.org/10.1890/14-0395.1.

Mayer, M., Wurtz, A., Jülich, R., Roller, G., \& Tappeser, B. (1995). Anforderungen an die Überwachung von Freisetzungen gentechnisch veränderter Pflanzen und Mikroorganismen als Landesaufgabe im Rahmen des Vollzugs des Gentechnikgesetzes. Naturschutz und Raumordnung, Sachsen-Anhalt: Ministerium für Umwelt.

McCartney, H. A., \& Lacey, M. E. (1991). Wind dispersal of pollen from crops of oilseed rape (Brassica napus L.). Journal of Aerosol Science, 22, 467-477.

Mccauley, R., Davies, M. \& Wyntje, A. (2012). The step-wise approach to adoption of genetically modified (gm) canola in Western Australia. 
Menzel, G. (2006). Verbreitungsdynamik und Auskreuzungspotential von Brassica napus L.(Raps) im Großraum Bremen. GCA-Verlag, Waabs. ISBN 3-89863-213-X.

Menzel, G., Born, A. (2004). Abschnitt B2: Mittlere Darstellungsebene: Empirische Analyse der Verbreitung von Raps und Kreuzungspartnern in Bremen und im Bremer Umland. In Der Forschungsverbund GenEERA (Generische Erfassung Und Extrapolation Der RapsAusbreitung). Abschlussbericht and Das Bundesministerium Für Bildung Und Forschung. Universität Bremen.

Mesquida, J., Renard, M., \& Pierre, J.-S. (1988). Rapeseed (Brassica napus L.) Productivity: The effect of honeybees (Apis mellifera L.) and different pollination conditions in cage and field tests. Apidologie, 19, 51-72.

Messean, A., Angevin, F., Go'mez-Barbero, M., Menrad, K., \& Rodríguez-Cerezo, E. (2006). New case studies on the coexistence of GM and non-GM crops in European agriculture. JRC-IPTSESTO Technical report series EUR $22102 \mathrm{EN}$.

Messeguer, J., Peñas, G., Ballester, J., Bas, M., Serra, J., Salvia, J., et al. (2006). Pollen-mediated gene flow in maize in real situations of coexistence. Plant Biotechnology Journal, 4, 633-645.

Metz, P. L. J., Jacobsen, E., Nap, J. P., Pereira, A., \& Stiekema, W. J. (1997). The impact on biosafety of the phosphinothricin-tolerance transgene in inter-specific $B$. rapa $\times$ B. napus hybrids and their successive backcrosses. Theoretical and Applied Genetics, 95, 442-450.

Middelhoff, U., Reuter, H., \& Breckling, B. (2011). GeneTraMP, a spatio-temporal model of the dispersal and persistence of transgenes in feral, volunteer and crop plants of oilseed rape and related species. Ecological Indicators, 11, 974-988.

Mikkelsen, T. R., Andersen, B., \& Jørgensen, R. B. (1996). The risk of crop transgene spread. Nature, $380,31$.

Mizuguti, A., Yoshimura, Y., Shibaike, H., \& Matsuo, K. (2011). Persistence of feral populations of Brassica napus originated from spilled seeds around the Kashima seaport in Japan. Japan Agricultural Research Quarterly: JARQ, 45, 181-185.

Moser, D., Eckerstorfer, M., Pascher, K., Essl, F., \& Zulka, K. P. (2013). Potential of genetically modified oilseed rape for biofuels in Austria: Land use patterns and coexistence constraints could decrease domestic feedstock production. Biomass and Bioenergy, 50, 35-44. https://doi.org/10. 1016/j.biombioe.2012.10.004.

National Academies of Sciences. (2016). Gene drives on the horizon: Advancing science, navigating uncertainty, and aligning research with public values. The National Academies Press, Washington, DC. https://doi.org/10.17226/23405

Neemann, G., \& Scherwaß, R. (1999). Materialen für ein Konzept zum Monitoring von Umweltwirkungen gentechnisch veränderter Pflanzen. UBA-Texte 52/99, Berlin.

Nishizawa, T., Nakajima, N., Aono, M., Tamaoki, M., Kubo, A., \& Saji, H. (2009). Monitoring the occurrence of genetically modified oilseed rape growing along a Japanese roadside: 3-year observations. Environmental Biosafety Research, 8, 33-44.

Noble, C., Min, J., Olejarz, J., Buchthal, J., Chavez, A., Smidler, A. L., DeBenedictis, E. A., Church, G. M., Nowak, M. A., \& Esvelt, K. M. (2016). Daisy-chain gene drives for the alteration of local populations.

Norris, C., \& Sweet, J. (2002). Monitoring large scale releases of genetically modified crops (EPG 1/5/84): Incorporating report on project EPG 1/5/30-monitoring releases of genetically modified crop plants. DEFRA Report, EPG, 1, 84.

Norris, C. E., Simpson, E. C., Sweet, J. B., Thomas, J. E. (1999). Monitoring weediness and persistence of genetically modified oilseed rape (Brassica napus) in the UK. Monograph-British Crop Protection Council, 255-260.

OECD. (1997). Consensus document on the biology of Brassica napus L. (oilseed rape), OECD, Series on harmonization of regulatory oversight in biotechnology.

Organisation for Economic Co-operation and Development OECD. (2012). Consensus document on the biology of brassica crops (Brassica spp.). 
Osborne, J. L., Clark, S. J., Morris, R. J., Williams, I. H., Riley, J. R., Smith, A. D., et al. (1999). A landscape-scale study of bumble bee foraging range and constancy, using harmonic radar. Journal of Applied Ecology, 36, 519-533.

Oye, K. A., Esvelt, K., Appleton, E., Catteruccia, F., Church, G., Kuiken, T., Lightfoot, S. B., McNamara, J., Smidler, A., \& Collins, J. P. (2014). Regulating gene drives. Science (New York, N.Y.) 345, 626-628. https://doi.org/10.1126/science.1254287

Pascher, K., \& Dolezel, M. (2005). Koexistenz von gentechnisch veränderten, konventionellen und biologisch angebauten Kulturpflanzen in der österreichischen LandwirtschaftHandlungsempfehlungen aus ökologischer Sicht. Forschungsauftrag des Bundesministeriums für Gesundheit und Frauen, Sektion IV., Bundesministerium für Gesundheit u. Frauen, Sekt. IV.

Pascher, K., \& Gollmann, G. (1999). Ecological risk assessment of transgenic plant releases: An Austrian perspective. Biodiversity \& Conservation, 8, 1139-1158.

Pascher, K., Hainz-Renetzeder, C., Gollmann, G., \& Schneeweiss, G. M. (2017). Spillage of viable seeds of oilseed rape along transportation routes: Ecological risk assessment and perspectives on management efforts. Frontiers in Ecology and Evolution, 5, 104.

Pascher, K., Macalka, S., Rau, D., Gollmann, G., Reiner, H., Glössl, J., \& Grabherr, G. (2010). Molecular differentiation of commercial varieties and feral populations of oilseed rape (Brassica napus L.). BMC Evolutionary Biology, 10, 63.

Pascher, K., Macalka-Kampfer, S., \& Reiner, H. (2000). Vegetationsökologische und genetische Grundlagen für die Risikobeurteilung von Freisetzungen von transgenem Raps und Vorschläge für ein Monitoring, Bundesministerium f. soziale Sicherheit und Generationen, Forschungsberichte $7 / 2000$.

Pascher, K., Narendja, F., Rau, D. (2006). Feral oilseed rape: Investigations on its potential for hybridisation; Final Report in Commission of the Federal Ministry of Health and Women (BMGH), Section IV; GZ: 70420/0116-IV/B/12/2004. Bundesministerium für Gesundheit u. Frauen.

Pekrun, C. (1994). Untersuchungen zur sekundären Dormanz bei Raps (Brassica napus L.). Cuvillier.

Pekrun, C., Lutman, P. J. W., \& Baeumer, K. (1997). Germination behaviour of dormant oilseed rape seeds in relation to temperature. Weed Research, 37, 419-431.

Pekrun, C., Ripfel, H., Albertin, A., Lutman, P. J. W., \& Claupein, W. (1998). Einfluß der Bodenbearbeitung auf die Ausbildung einer Samenbank bei Raps - Ergebnisse von sechs Standorten in England und einem in Österreich im Jahre 1997. Mitteilungen der Gesellschaft für Pflanzenbauwissenschaften, 11, 51-52.

Pessel, D., Lecomte, J., Emeriau, V., Krouti, M., Messean, A., \& Gouyon, P. H. (2001). Persistence of oilseed rape (Brassica napus L.) outside of cultivated fields. Theoretical and Applied Genetics, 102, 841-846. https://doi.org/10.1007/s001220100583.

Pivard, S., Adamczyk, K., Lecomte, J., Lavigne, C., Bouvier, A., Deville, A., et al. (2008). Where do the feral oilseed rape populations come from? A large-scale study of their possible origin in a farmland area. Journal of Applied Ecology, 45, 476-485.

Prentis, P. J., Wilson, J. R., Dormontt, E. E., Richardson, D. M., \& Lowe, A. J. (2008). Adaptive evolution in invasive species. Trends in Plant Science, 13, 288-294.

Rakow, G., \& Woods, D. L. (1987). Outcrossing in rape and mustard under Saskatchewan prairie conditions. Canadian Journal of Plant Science, 67, 147-151.

Ramsay, G., Thompson, C., Squire, \& G. R. (2003). Quantifying landscape-scale gene flow in oilseed rape. Final Report of Defra Project 1-50.

Ramsey, G., Thompson, C. E., Neilson, S., \& Mackay G. R. (1999). Honeybees as vectors of GM oilseed rape pollen. BCPC Symposium Proceedings 72.

Raybould, A. F., \& Gray, A. J. (1993). Genetically modified crops and hybridization with wild relatives: A UK perspective. Journal of Applied Ecology 199-219.

Reeves, R. G., \& Reed, F. A. (2015). Stable transformation of a population and a method of biocontainment using haploinsufficiency and underdominance principles. 
Reuter, H., Menzel, G., \& Breckling, B. (2008). Hazard mitigation or mitigation hazard? Environmental Science and Pollution Research, 15, 529-535.

Rieger, M. A., Potter, T. D., Preston, C., \& Powles, S. B. (2001). Hybridisation between Brassica napus L. and Raphanus raphanistrum L. under agronomic field conditions. Theoretical and Applied Genetics, 103, 555-560.

Ringdahl, E. A., McVetty, P. B. E., \& Sernyk, J. L. (1987). Intergeneric hybridization of Diplotaxis spp. with Brassica napus: A source of new CMS systems? Canadian Journal of Plant Science, 67, 239-243.

Röbbelen, G. (1986). Anbau von 00-Raps in der Bundesrepublik Deutschland 1984/85. Raps, 4, 4-10.

Roller, A., Beismann, H., \& Albrecht, H. (2001). Monitoring of the persistence of GM oil seed rape seeds in field trials. Verhandlungen der GfÖ, 31, 250.

Saji, H., Nakajima, N., Aono, M., Tamaoki, M., Kubo, A., Wakiyama, S., et al. (2005). Monitoring the escape of transgenic oilseed rape around Japanese ports and roadsides. Environmental Biosafety Research, 4, 217-222.

Salisbury, P. (1989). Potential utilization of wild crucifer germplasm in oilseed Brassica breeding. In Proceeding ARAB 7th Workshop (pp. 51-33), Toowoombu, Queensland, Australia.

Salisbury, P. A. (1991). Genetic variability in Australian wild crucifers and its potential utilisation in oilseed Brassica species (Ph.D.-thesis). La trobe University.

Sarwar, M. F., Sarwar, M. H., Sarwar, M., Qadri, N. A., \& Moghal, S. (2013). The role of oilseeds nutrition in human health: A critical review. Journal of Cereals and Oilseeds, 4, 97-100.

Saure, C., Kühne, S., \& Hommel, B. (1999). Untersuchungen zum Pollentransfer von transgenem Raps auf verwandte Kreuzblütler durch Wind und Insekten. Presented at the Proceedings zum BMBF-Statusseminar (p. 30).

Saure, C., Kühne, S., \& Hommel, B. (1999). Auswirkung des Anbaus gentechnisch veränderter Rapspflanzen auf blütenbesuchende Bienen (Apidae) und Schwebfliegen (Syrphidae). Jahresbericht der BBA 1999, Berlin und Braunschweig.

Sauremann, W. (1987). Entwicklung des Glucosinolatgehaltes von 00-Raps in den nächsten 10 Jahren in Abhängigkeit vom Fremddurchwuchs. Raps, 1, 12-13.

Schafer, M. G., Ross, A. A., Londo, J. P., Burdick, C. A., Lee, E. H., Travers, S. E., et al. (2011). The establishment of genetically engineered canola populations in the US. PLoS ONE, 6, e25736.

Scheffler, J. A., \& Dale, P. J. (1994). Opportunities for gene transfer from transgenic oilseed rape (Brassica napus) to related species. Transgenic Research, 3, 263-278.

Scheffler, J. A., Parkinson, R., \& Dale, P. J. (1993). Frequency and distance of pollen dispersal from transgenic oilseed rape (Brassica napus). Transgenic Research, 2, 356-364.

Schlink, S. (1998a). 10 Jahre Überdauerung von Rapssamen (Brassica napus L.) im Boden. Mitteilungen der Gesellschaft für Pflanzenbauwissenschaften, 11, 221-222.

Schlink, S. (1998b). 10 years survival of rape seed (Brassica napus L.) in soil. ZEITSCHRIFT FUR PFLANZENKRANKHEITEN UND PFLANZENSCHUTZ-SONDERHEFT-, 16, 169-172.

Schlink, S. (1994). Ökologie der Keimung und Dormanz von Körnerraps (Brassica napus L.) und ihre Bedeutung für eine Überdauerung der Samen im Boden. Dissertationes Botanicae.

Schmidt, G., \& Schröder, W. (2011). Regionalisation of climate variability used for modelling the dispersal of genetically modified oil seed rape in Northern Germany. Ecological Indicators, 11, 951-963.

Schoenenberger, N., \& D'Andrea, L. (2012). Surveying the occurrence of subspontaneous glyphosate-tolerant genetically engineered Brassica napus L. (Brassicaceae) along Swiss railways. Environmental Sciences Europe, 24, 23.

Schulze, J., Brodmann, P., Oehen, B., \& Bagutti, C. (2015). Low level impurities in imported wheat are a likely source of feral transgenic oilseed rape (Brassica napus L.) in Switzerland. Environmental Science and Pollution Research, 22, 16936-16942.

Schulze, J., Frauenknecht, T., Brodmann, P., \& Bagutti, C. (2014). Unexpected diversity of feral genetically modified oilseed rape (Brassica napus L.) despite a cultivation and import ban in Switzerland. PLoS One 9, e114477. 
Scott, S., \& Wilkinson, M. (1998). Transgenic risk is low. Nature, 393, 320.

Sikka, Sm. (1940). Cytogenetics of Brassica hybrids and species. Journal of Genetics, 40, 441-474.

Simard, M.-J., Légère, A., Séguin-Swartz, G., Nair, H., \& Warwick, S. (2005). Fitness of double versus single herbicide-Resistant canola. Weed Science, 53, 489-498.

Simard, M.-J., Légère, A., \& Warwick, S. I. (2006). Transgenic Brassica napus fields and Brassica rapa weeds in Quebec: Sympatry and weed-crop in situ hybridization. Botany, 84, 1842-1851.

Simpson, E. C., Norris, C. E., Law, J. R., Thomas, J. E., \& Sweet, J. B. (1999). Gene flow in genetically modified herbizide tolerant oilseed rape (Brassica napus) in the UK. BCPC Symposium Proceedings, 72.

Snow, A. A. (2002). Transgenic crops-Why gene flow matters. Nature Biotechnology, 20, 542.

Sobrino-Vesperinas, E. (1988). Obtainment of some new intergeneric hybrids between wild Brassiceae. Candonella, 43, 499-504.

Song, K. M., Osborn, T. C., \& Williams, P. H. (1990). Brassica taxonomy based on nuclear restriction fragment length polymorphisms (RFLPs) 3. Genome relationships in Brassica and related genera and the origin of B. oleracea and B. rapa (syn. campestris). Theoretical and Applied Genetics, $79,497-506$.

Squire, G., Crawford, J., Ramsey, G., \& Thompson, C. E. (1999). BCPC Symposium Proceedings, $72,57-64$.

Squire, G. R., Breckling, B., Pfeilstetter, A. D., Jorgensen, R. B., Lecomte, J., Pivard, S., et al. (2011). Status of feral oilseed rape in Europe: Its minor role as a GM impurity and its potential as a reservoir of transgene persistence. Environmental Science and Pollution Research, 18, 111-115.

Stace, C. (2010). New flora of the British Isles. Cambridge University Press.

Tamis, W. L. M., \& De Jong, T. J. (2010). Transport chains and seed spillage of potential GM crops with wild relatives in the Netherlands (pp. 2010-2102). COGEM report: CGM.

Thomas, D. D., Donnelly, C. A., Wood, R. J., \& Alphey, L. (2000). Insect population control using a dominant, repressible, lethal genetic system. Science, 287, 2474-2476.

Timmons, A. M., O’Brien, E. T., Charters, Y. M., Dubbels, S. J., \& Wilkinson, M. J. (1995). Assessing the risks of wind pollination from fields of genetically modified Brassica napus ssp. oleifera. In The methodology of plant genetic manipulation: Criteriafor decision making (pp. 417423). Springer.

Treu, R., \& Emberlin, J. (2000). Pollen dispersal in the crops Maize (Zea mays), Oil seed rape (Brassica napus ssp. oleifera), Potatoes (Solanum tuberosum), Sugar beet (Beta vulgaris ssp. vulgaris) and Wheat (Triticum aestivum). Evidence from publications. A report for the Soil Association from the National Pollen Research Unit, University College Worcester.

United States Department of Agriculture-USDA (2018). Oilseeds: World markets and trade.

von der Lippe, M., \& Kowarik, I. (2007). Crop seed spillage along roads: A factor of uncertainty in the containment of GMO. Ecography, 30, 483-490.

Vullioud, P. (1992). Densité de semis en culture de colza d'automne. Rev Suisse Agric, 24, 345-350.

Waddington, K. D., Herbert, T. J., Visscher, P. K., \& Richter, M. R. (1994). Comparisons of forager distributions from matched honey bee colonies in suburban environments. Behavioral Ecology and Sociobiology, 35, 423-429.

Warwick, S. I. (1997). Use of biosystematic data, including molecular phylogenies, for biosafety evaluation. Presented at the JIRCAS International Symposium Series (Japan).

Warwick, S. I., Legere, A., SIMARD, M.-J., James, T. (2008) Do escaped transgenes persist in nature? The case of an herbicide resistance transgene in a weedy Brassica rapa population. Molecular Ecology, 17, 1387-1395

Warwick, S. I., Simard, M.-J., Légère, A., Beckie, H. J., Braun, L., Zhu, B., et al. (2003). Hybridization between transgenic Brassica napus L. and its wild relatives: Brassica rapa L., Raphanus raphanistrum L., Sinapis arvensis L., and Erucastrum gallicum (Willd.) OE Schulz. Theoretical and Applied Genetics, 107, 528-539. 
Wilkinson, M. J., Timmons, A. M., Charters, Y., Dubbels, S., Robertson, A., Wilson, N., Scott, S., O'Brien, E., Lawson, H. M. (1995). Problems of risk assessment with genetically modified oilseed rape. Presented at the Brighton crop protection conference: Weeds. Proceedings of an international conference, Brighton, UK, 20-23 November 1995. British Crop Protection Council, pp. 1035-1044.

Yoshimura, Y., Beckie, H. J., \& Matsuo, K. (2006). Transgenic oilseed rape along transportation routes and port of Vancouver in western Canada. Environmental Biosafety Research, 5, 67-75.

Zander, P. (2003). Agricultural land use and conservation options-A modelling approach. Dissertation, Wageningen University. 240.

Open Access This chapter is licensed under the terms of the Creative Commons Attribution 4.0 International License (http://creativecommons.org/licenses/by/4.0/), which permits use, sharing, adaptation, distribution and reproduction in any medium or format, as long as you give appropriate credit to the original author(s) and the source, provide a link to the Creative Commons license and indicate if changes were made.

The images or other third party material in this chapter are included in the chapter's Creative Commons license, unless indicated otherwise in a credit line to the material. If material is not included in the chapter's Creative Commons license and your intended use is not permitted by statutory regulation or exceeds the permitted use, you will need to obtain permission directly from the copyright holder.

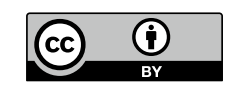

